Portland State University

PDXScholar

1973

\title{
Granulometric analysis of recent sediments of Tillamook Bay, Oregon
}

Gennaro William Avolio

Portland State University

Follow this and additional works at: https://pdxscholar.library.pdx.edu/open_access_etds

Part of the Geology Commons

Let us know how access to this document benefits you.

\section{Recommended Citation}

Avolio, Gennaro William, "Granulometric analysis of recent sediments of Tillamook Bay, Oregon" (1973). Dissertations and Theses. Paper 1928.

https://doi.org/10.15760/etd.1927

This Thesis is brought to you for free and open access. It has been accepted for inclusion in Dissertations and Theses by an authorized administrator of PDXScholar. Please contact us if we can make this document more accessible: pdxscholar@pdx.edu. 


\title{
GRANULONETRIC ANALYSIS OF RECENT SEDIMENTS \\ OF TILIAMDOK BAY, OREGON
}

\section{by}

GENNARO WILLIAM AVOLIO

A thesis submitted in partial fulfillment of the requilrements for the degree of

\author{
MASTER OF SCIENCE \\ in \\ EARPH SCIENCE
}

Portland State University

1973 
AN ABSTRACT OF THE THESIS OF Gennaro William Avolio for the Master of Science in Earth Science presented May 24, 1973.

Title: Granulometric Analysis of Recent sediments of Tillamook Bay, Oregon

APPROVBD BY MEMBERS OF THE THESIS COMMITTEE:

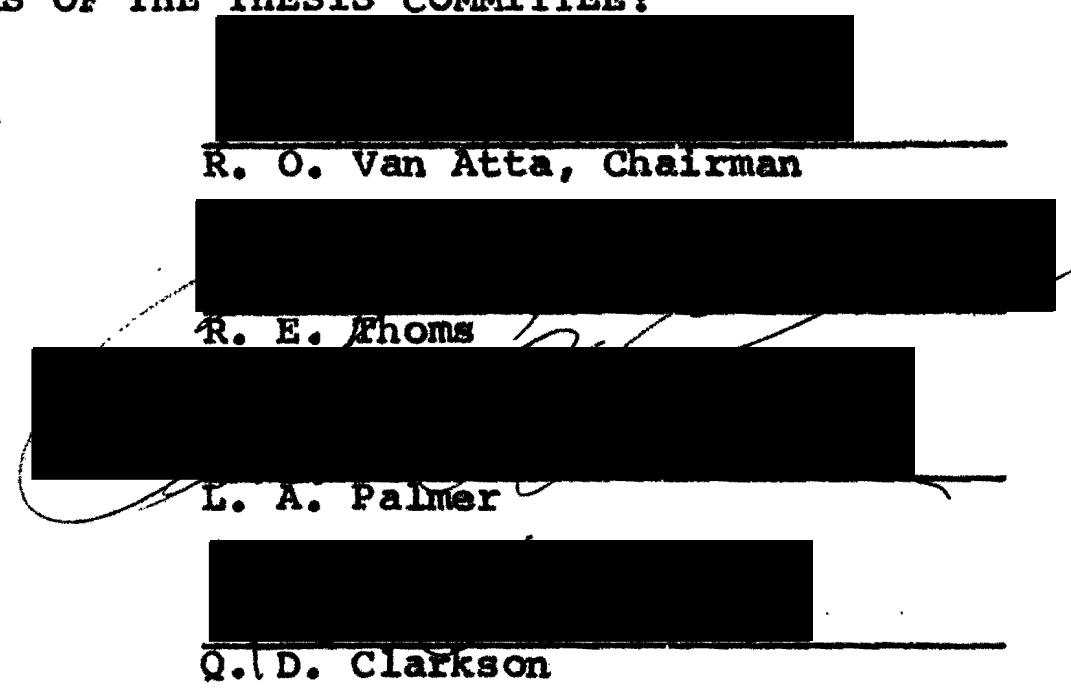

The author has sampled the recent bottom sediments in Tillamook Bay, Oregon. Sediment distribution is assessed in relation to sediment source areas and related to sedimentary environments. Particular attention was directed to the precision with which granulometric data can be stated. It was found that variance is quite high for granulometric parameters of the bay sediments. Sediment distribution using different measures are displayed on charts of the bay. Size distributions of sediments at any given location are examined for geologic 
significance. Plotting of size distributions on graph paper using probability ordinate is shown to increase the ease of geologic interpretation.

Total heavy minerals were $X-r a y e d$ and provenance determinations from this and other data show a marine sediment source for a small area of the bay near the mouth and terrestrial source for the remainder of the bay. 
TO THE OFFICE OF GRADUATE STUDIES:

The members of the Committee approve the thesis of Gennaro William Avolio presented May 24,. 1973.

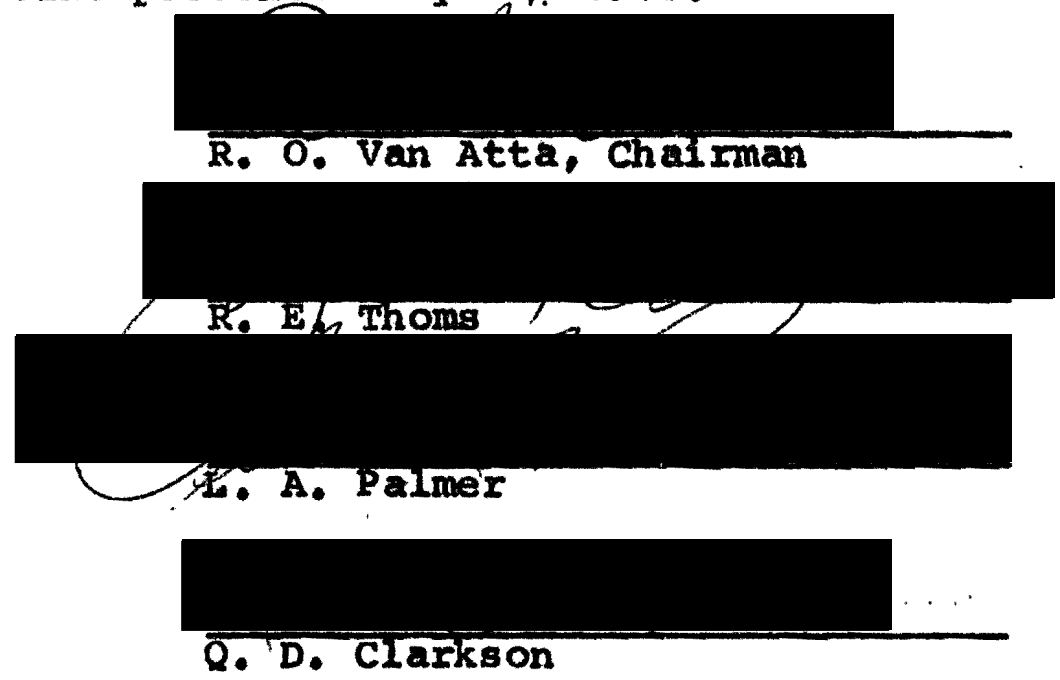

APPROVED 8

Yohp E. Afien, Head, Department or Earth Science

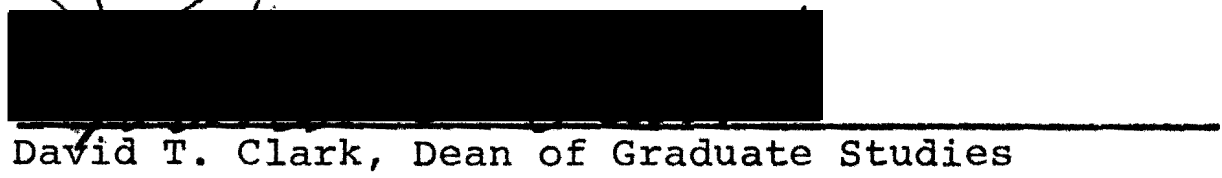




\section{ACKNOWLEDGMENTS}

The bottom materials samplex used for this study is the property of the United States Geologieal Survey. I wish to thank Dr. Jerry Glenn of the survey for his assistanco and helpfulness in putting resouroes at my disposal.

I also wish to thank Dr. R. E. Thoms of the Department of Earth science, Portland state University, for many helpful suggestions and for serving as a member of my committee. Dr. I. A. Palmer of the Department of Earth Science, Portland State University, served as a comaittee member and provided valuable counsel and is due my gratitude.

Many thanks are due to Dr. J. E. Allen, Head, Department of Earth Science, Portland State University, for his help in critical review of this work.

My sincerest thanks to Dr. R. O. Van Atta of the Department of Earth Science, Portland state University. for his encouragement and support during my studies at Portland State and also for assuming the burden of acting as my major advisor.

Dr. Q. D. Clarkson of the Department of Soclal Work, Portland state university, spent many hours with criticlsm 
and suggestions on the statistical aspects of this study. I wish to thank him for his competent support.

I would also like to thank Miss Janie Monroe for many hours of assistance in writing and "debugging" the computer program.

Lastly, my wife, Marilyn, has contributed more than any single person to the success of this project. She acted as my field assistant, my laboratory assistant, and she has typed both the drafts and final manuscript. This project would not have been completed without her. 


\section{LIST OF TABIES}

TABIE

PAGE

I Nested Analysis of Variance Table

$$
\text { (Preliminary stations) . . . . . . }
$$

II Analysis of Variance Statistics

(Preliminary Samples) . . . . . .

III F Ratios and Between station Minimum

Resolvable Differences for Granulometric

Variables (Preliminary Samples) . . .

IV Nested Analysis of Variance Table

(Population Total) . . . . . . .

V Analysis of Variance statistics

(Population Total) . . . . . . .

VI F Ratios and Between Station Minimum

Resolvable Differences for Granulometric

Variables (Population Total) . . .

VII F Ratios and Between Station Minimum

Regolvable Differences for Granulometric

Variables (subpopulations Defined by

Water Depth) . . . . . . . . . 
IIST OF FIGURES

FIGURE

PAGE

1 Sketch map of the northern coast of Oregon . . . . . . . . . . . .

2 Bathymetry and station locations in

Tillamook Bay . . . . . . . . . 10

3 Cut and fill areas in Tillamook Bay . . . 13

$4 a$ B. M. 54 sampler ready to take sample . . 25

4b B. M. 54 sampler after taking sample . . . 25

5 Distribution of median grain size of sediments in Tillamook Bay . . . .

6 Distribution of sediment type in

Tillamook Bay . . . . . . . . . .

7 Distribution of skewness and sorting of sediments in Tillamook Bay . . . •

8 Plot of the coarsest 1 percentile versus median grain size for those stations that were skewed to the coarse . . .

9 Sediment cumulative curve types in

Tillamook Bay, . - . - . . - .

10 Synthesized curve derived from two normal curves .......... ......... 
11 X-ray diffraction "fingerprints" of heavy mineral samples from the northern part of Tillamook Bay . . . . . . .

$12 a$ X-ray diffraction "fingerprints" of heavy mineral samples from four rivers that flow into Tillamook Bay ........

$12 b$ X-ray diffraction "fingerprints" of heavy mineral samples from the southern part of Tillamook Bay :. . . . . . .

13a Electron photomicrograph of a sample of the less than 2 micron suspended sediment in Tillamook Bay . . . . . . . . .

13b Electron photomicrograph of a sample of the less than 2 micron suspended sediment in Tillamook Bay . . . . . . . . 
TABLE OF CONTENTS

PAGE

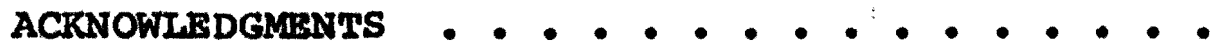

ii1

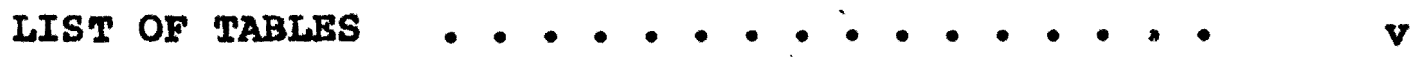

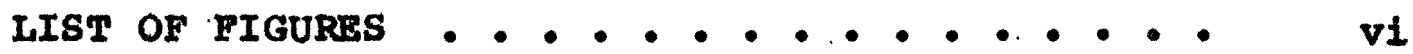

INTRODUCTION

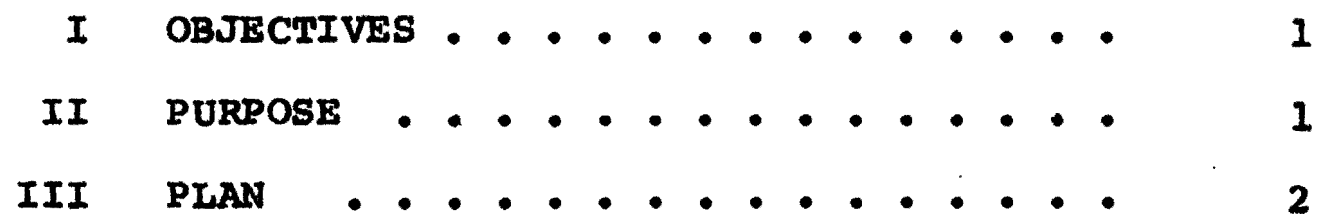

BACKGROUND INFORMATION

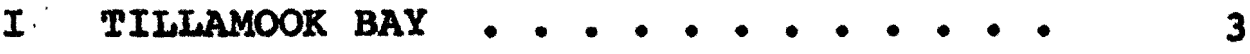

II PHYSIOGRAPHY • • • • • • • • • 3

III CLIMATE $\bullet \cdot \cdot \cdot \cdot \cdot \cdot \cdot \cdot \cdot \cdot \cdot \cdot \cdot 6$

IV REGIONAL GEOLOGY • - • - . - . . 7

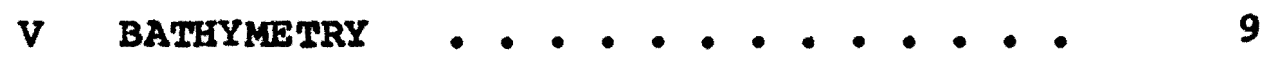

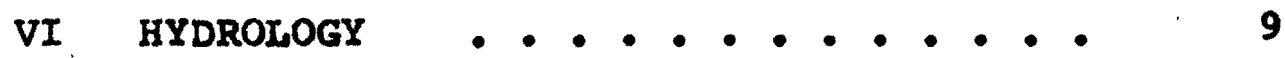

VII CUT AND FILI . . . . . . . . . . 12

VII CIIMATIC INFLUENCE •. . . . . . $\quad 14$

IX ESTUARINE CURRENTS • • • • • • • . 15

X PREVIOUS WORK. . . . . . . . . . 16

INVESTIGATIVE PROCEDURES AND RESULTS

I FIELD SAMPLING PLAN • . . . . . . 17

II TEXTURAI ANALYSIS . . . . . . . . 26 
PAGE

III hEAVY MINERAI ANALYSIS • • • • . 27

IV CLAY MINERAL ANALYSIS . . . . . . 27

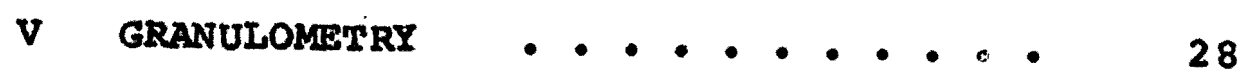

Analysis of Variance . . . . . 28

Skewness and Sorting . . . . . 35

Subpopulation Statistics . . . $\quad 39$

Cummulative Curves . . . . . . 42

vI MINERALOgY ... . . . . . . . . 48

Heavy Mineralogy . . . . . . , . 48

Clay Mineralogy . . . . . . $\quad 53$

SUMMARY

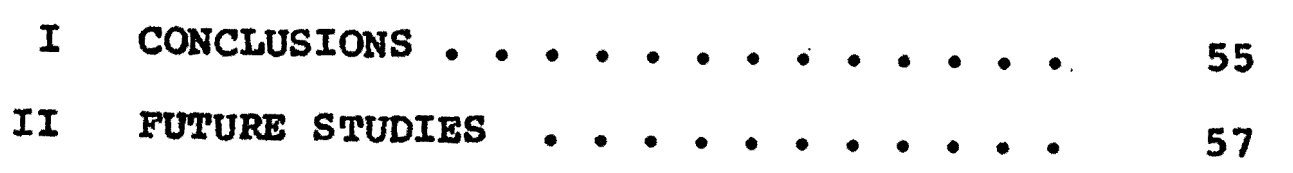

REFERENCES CITED •. . . . . . . . . . 58

APPENDIX ... . . . . . . . . . . . . . . 62 


\section{INTRODUCTION}

\section{OBJECTIVES}

The objectives of this study are:

1. To describe the sediments in Tillamook Bay in granulometric terms and to display their areal distributions in a pictorial manner,

2. To determine mathematically the precision with which the granulometric data can be stated,

3. To relate the sediment distribution to the sedimentary environment,

4. To assess the relationship of source areas to sediment distribution.

\section{PURPOSE}

Tillamook Bay was chosen for this study as the bay provided several sedimentary environments and these environments would be reflected in the sediment distribution.

No previous sedimentation studies of Tillamook Bay are known. With the increased public interest and emphasis on estuaries, studies are needed to provide comparative data for the future. 


\section{PLAN}

Samples were taken in the shortest possible time to reduce the effects of change within the bay on results. Laboratory work was completed during the following academic year. Data is displayed primarily in a pictorial manner on maps or charts. 


\section{BACKGROUND INFORMATION}

\section{TILIAMOOK BAY}

Tillamook Bay is approximately 10 kilometers (6 miles) long and 5 kilometers ( 3 miles) wide, the greatest dimension being in a north south direction. The area of the bay is nearly 36 square kilometers (14 square miles) at high water and slightly over 19 square kilometers ( 7 and $1 / 2$ square miles) at low water. The Corps of Engineers uses a figure of 58,000 acre feet for the tidal prism.

Five rivers flow into the bay, the Miami, Kilchis, Wilson, Trask and Tillamook, and together drain an area of about 1,450 square kilometers (570 square miles).

\section{PHYSIOGRAPHY}

Tillamook Bay (Figure 1) and the five major drainage basins associated with it, are located on the western side of the Oregon Coast Range in the northwest part of oregon. The coastline of northern oregon has been described by Kulm and Byrne (1966) as "... a series of beaches interrupted by exosionally resistant headlands and numerous estuaries." On the headlands in the vicinity of Tillamook Bay and on higher ground further inland, 


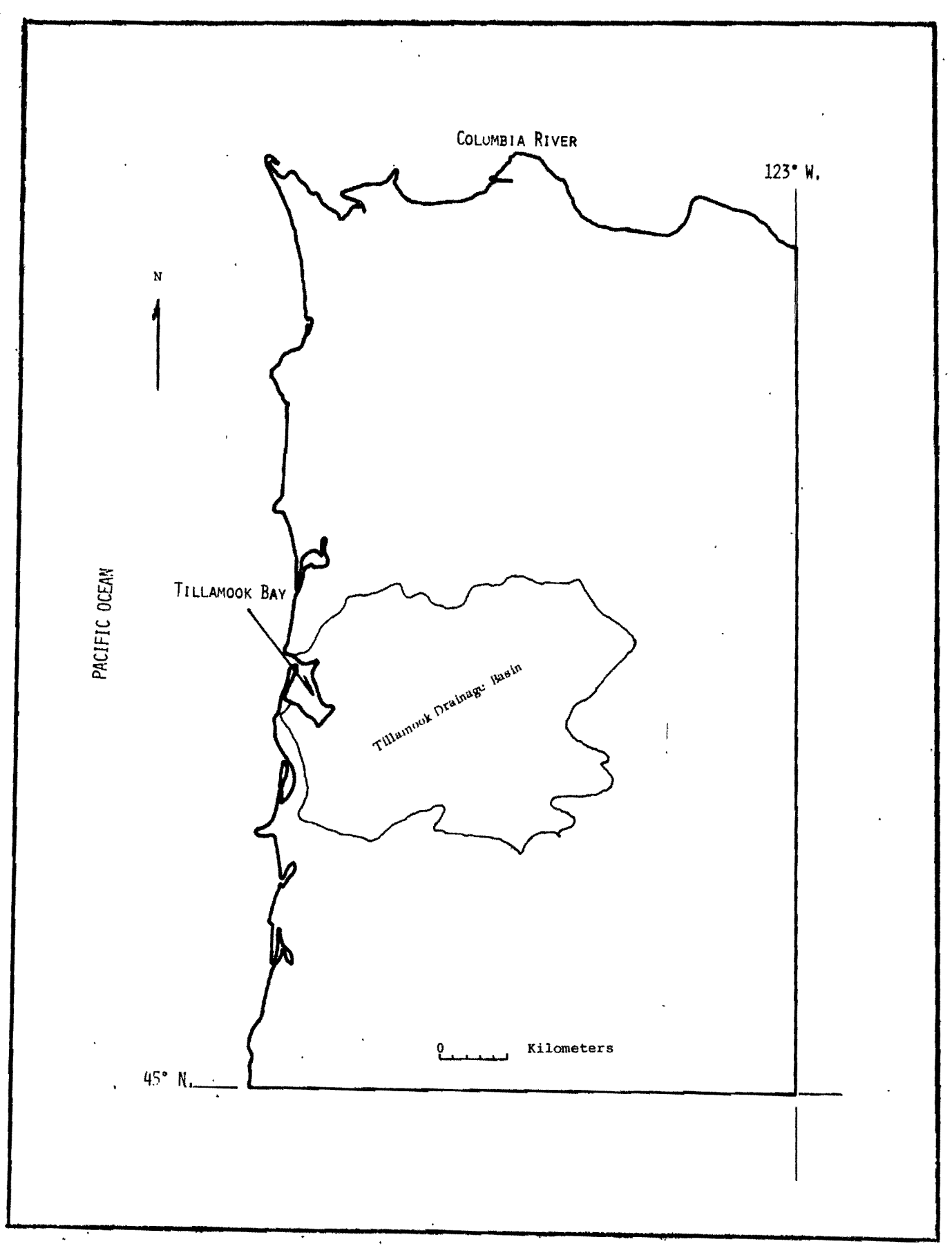

Fiqure 1. Sketch map of the northern coast of Oregon showing Tillamook Bay and associated drainage basin. 
uplifted marine terraces are found. Palmer (1967) identifies an extensive well developed terrace at approximately 130 meters (400 feet) elevation and a terrace at the 250 meters to 300 meters $(800$ to 900 feet) elevation that is poorly preserved except on the headlands.

To the north of Tillamook Bay the coast consists of a relatively narrow, nearly straight beach with the foothills of the coast Range rising abruptly within 3 kilometers (two miles) to 550 meters (1700 feet). The outer beach is a typical narrow dune complex which has obstructed the drainage from the foothills. As a result, several fresh water lakes and marshes are located between the beach and the rising topography of the Coast Range. The north jetty, which protects the navigation channel to Tillamook Bay, is the southern terminus of the dune complex. This jetty was constructed between 1913 and 1917 and presently extends 2 kilometers (1.2 miles) westward. Comparison of the present coastline with a chart published by the United States Coast and Geodetic Survey in 1908 indicates that the beach has prograded westward about 0.9 kilometers $(0.6 \mathrm{miles})$ on the north side of the jetty. The exposed area of sand behind the jetty is now about. 1.0 square kilometers (0.4 square miles).

In 1927 the north jetty was extended to improve navigation into the bay. The present project depth of eighteen feet for the channel to the town of Garibaldi 
has been maintained fairly well with only infrequent dredging. In 1971 construction was started on a south jetty to further improve navigation into the bay. The outer spit that forms the western boundary of Tillamook Bay is composed of Recent and older (Pleistocene?) dune sand. This spit was breached by storm waves in the winter of 1952 . The break was repalred when a Corps of Engineers contract was let in 1956. To the south of the spit is Cape Meares, a bold headland composed primarily of Miocene volcanic rocks.

\section{CLIMATE}

The climate of the northern Oregon coastal area is one of cool, relatively dry summers and cool, wet winters. A mean annual precipitation of about 190 centimeters (75 inches) with mean summer temperature of $14^{\circ} \mathrm{C}\left(59^{\circ} \mathrm{F}\right)$ and mean winter temperature of $6^{\circ} \mathrm{C}\left(42^{\circ} \mathrm{F}\right)$ characterize the climate. Seasonal wind patterns have been described by Cooper (1958). Onshore winds from the north-northwest are the most common in spring, summer and fall. Most of the time during the winter months the winds are offshore with fairly low velocity. Winter storms, however, bring high velocity winds from the south to southwest. The dimensions and orientation of Tillamook Bay are such that both the north-northwest and southwest winds can build a quite extensive wave system at the north or south end of 
the bay.

IV REGIONAL GEOLOGY

The rivers that empty into the bay drain part of the western slope of the northern Coast Range. The rocks of the Coast Range consist of Tertiary volcanics, both submarine and subaerial, and marine sediments, gently folded into an anticlinorium, so that in the pillamook area dips are predominantly to the west. Geologic formations in the drainage area of the rivers flowing into Tillamook Bay include the Siletz River Volcanics, the Tillamook Volcanic series, the Nestucca Formation, Mlocene intrusive and flow rocks, and the Astoria Formation.

The Siletz River Volcanic Series is early Bocene and, as noted below, is correlative with the lower Tillamook Volcanic Series.

The term Tillamook Volcanic Series was assigned by Warren and others (1945) to an accumulation of Eocene volcanic rocks in northwestern oregon. The younger parts of this series are now referred to the Goble volcanics and the Nestucca Formation while the older parts are commonly referred to as parts of the Siletz. River Volcanic Series, originally described by Snavely and Baldwin (1948). It consists of some thousands of feet of maxine basaltic flows, pillows, flow breccias and pyroclastics. 
The mineralogy of the basalts consists of labradorite, augite and titaniferous magnetite as major constituents and calcite, stilbite, natrolite and mordenite as secondary minerals. Volcanic glass is found in varying amounts and chloxitization is ubiquitous. The pillow lavas of the lower section are tholeiltic and high in the section alkalic derivitives can be found locally (Snavely and others 1968).

The Nestucca Formation (Snavely and Vokes 1949) is composed of interbedded tuffaceous siltstones and claystones. In the lower part of the section some cross bedded and carbonaceous feldspathic sandstone is found. In the northern portion of the area, basaltic flows with associated pillows, brecclas and other pyroclastic rocks are found also. The Nestucca is late Eocene in age. Miocene intrusive and flow rocks of the Coast Range commonly are granophyric gabbro, composed of labradorite and augite with interstitial quartz, orthoclase and accessory minerals.

The Astoria Formation is described by Howe (1926), Dodds (1963), and Snavely and others (1969) among others. The lithology of rocks assigned to this formation is characteristically sandstone interbedded with what is called silty shale but in actuality are more properly called mud rocks as the fissillity is almost nonexistent. The sandstone is yellow to gray, massive to 
cross bedded, medium to fine grained and feldspathic. There are local areas of micaceous and tuffaceous beds. Rocks usually referred to be Astoria Formation contain beds that have been assigned ages from oligocene through late Miocene (Dodds 1956).

\section{BATHYMETRY}

The bathymetry of Tillamook Bay, as can be seen in Figure 2, is fairly complex with numerous dendritic channels. However, it may be divided into two zones:

1. Tidal channels and estuaries characterized by being under water except at the lowest tides, and

2. Tidal and grass flats that are exposed at low tide.

The major portion (over 70 percent) of the bay is in the latter classification.

That area to the south and east where the outline of the bay is not shown on Figure 2 is covered with vegetation and was not sampled in this study.

\section{HYDROLOGY}

Tillamook Bay has been classified by Burt and McAllister (1959) using the system of Prichard (1955). This system is based on salinity of water on the surface and bottom at selected sample locations. Burt and Mc- Allster use three definitions to classify Tillamook Bay. 


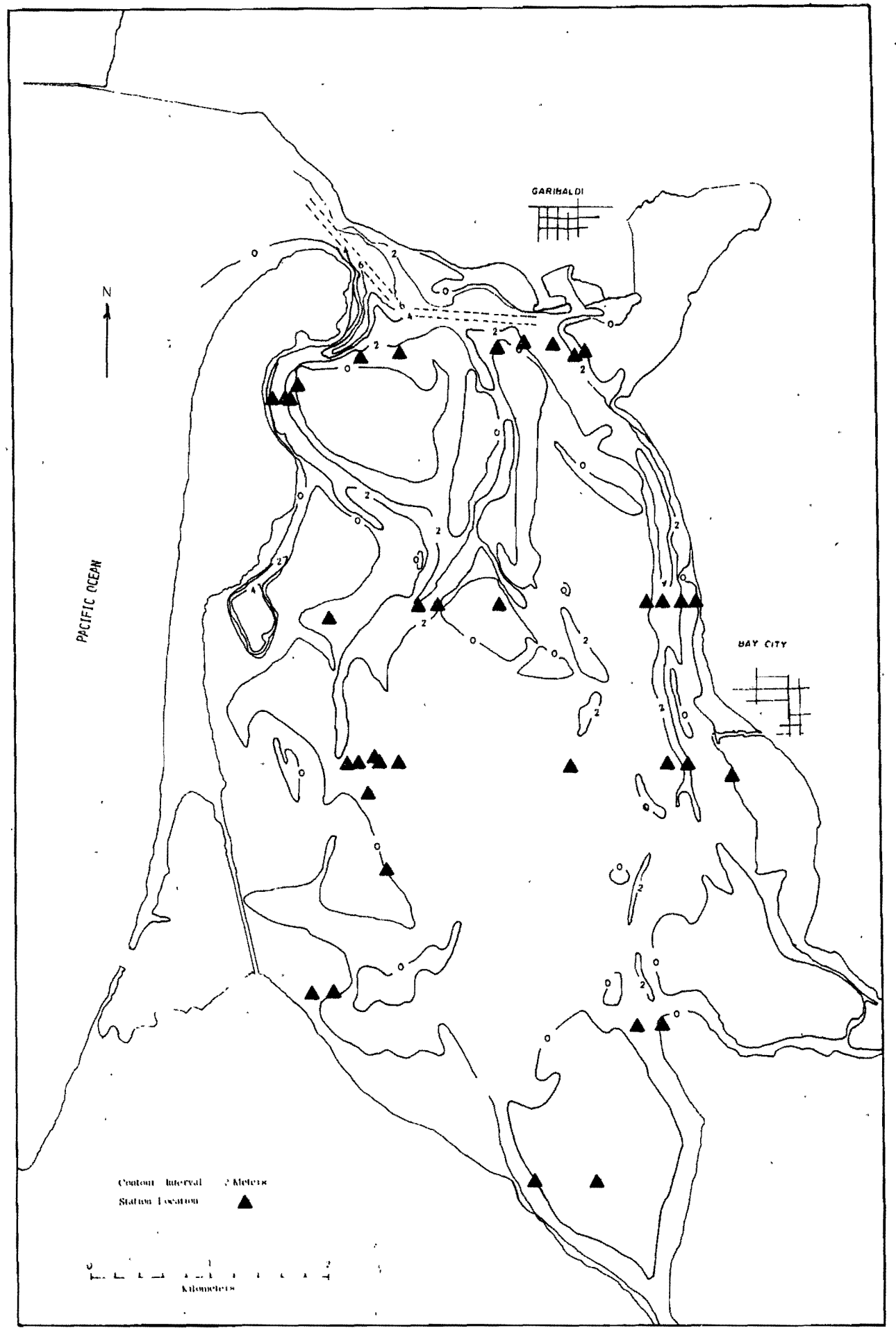

Figure 2. Bathymetry and station locations in Tillamook Bay. The zero reference datum is mean lower low water. 
When the difference in salinity between top and bottom water exceeds twenty parts per thousand the estuary is said to be two-layered. When the difference ranges between four and nineteen parts per thousand the area is classified as partly mixed, and when the difference is less than four parts per thousand, the area is well-mixed. Data reported by Burt and McAllister shows Tillamook Bay to be two-layered 10 kilometers $(6 \mathrm{miles})$ from the mouth of the bay in January. During April and October respectively, the bay is well-mixed 10 kilometers $(6$ miles) from the mouth and $13 \mathrm{kilometers}(8 \mathrm{miles})$ from the mouth. Their study was too limited to reveal the dates of transitions or any other fluctuations, which may occur.

The classification depends on the amount of tidal energy available and the amount of river discharge. The tidal energy remains more or less constant throughout the year while the runoff fluctuates seasonally. During times of low discharge tidal energy is capable of mixing the fresh water and sea water so that little or no change in salinity occurs from top to bottom. As Eresh water discharge increases, a point is reached where there is not enough energy to $\mathrm{mix}$ the salt and fresh water. Then vertically homogenous conditions no longer prevail and either partly mixed or two-layered conditions exist. As has been pointed out by Blanton (1969). 
flushing time, or the time for a particle to be flushed out of the estuary, is affected by fresh water discharge. A short flushing time is associated with high discharge and long flushing time with low discharge. Pollutants may remain in an estuary for a long time during periods of low discharge.

\section{CUT AND FILI}

A study of navigation bathymetric charts published since 1908 reveals that both erosion and deposition have been taking place in the bay with deposition being the dominant process. Figure 3 shows areas of cut and fill since 1928. (The year 1928. was chosen because of the possibility of earlier charts using a different reference datum.) The areas shown as fill in Figure 3 are those areas that are shallower on the current United States Coast and Geodetic Survey chart than on the 1928 chart. Those areas shown as cut, conversely, are areas that are deeper now than in 1928. Charts between 1928 and the present were checked to see if there were areas of changing process. Generally those areas shown as fill have been filling since 1928. Areas of cut have not been so stable and within the bay those areas shown as cut or erosion have not been constantly eroding since 1928. The United States Coast and Goodetic Survey charts are designed primarily for use by mariners and 


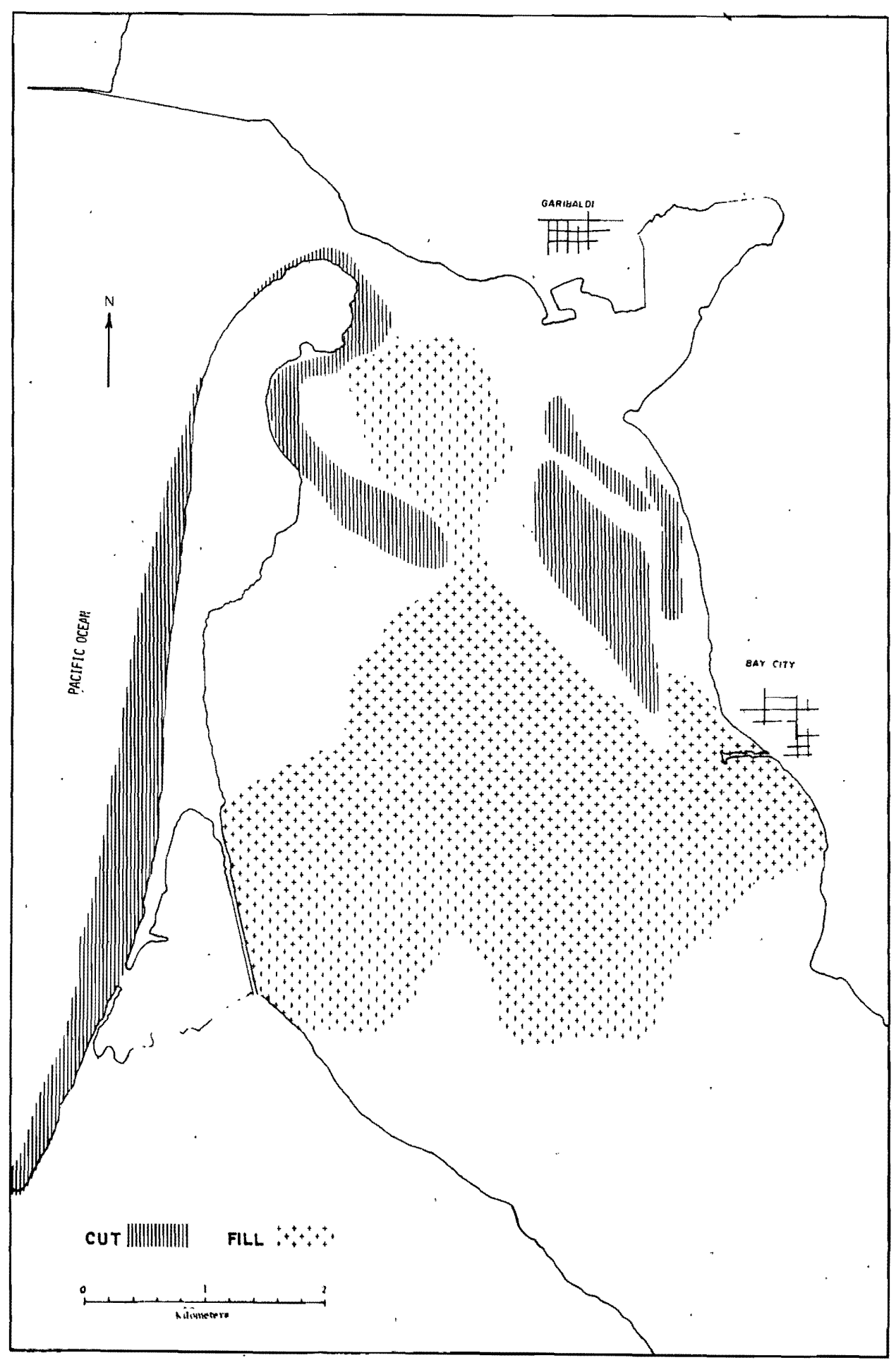

Figure 3. Cut and fill areas in Tillamook Bay. 
consequently do not show water depths less than zero. This means that filling can occur in these areas and no change will show on the charts. That portion of the bay to the south of the large fill area in the center of the bay is such an area and probably has filled also, even though not shown as fill in the figure. The general trend seems to be that the bay is filling from south to north.

\section{CLIMATIC INFLUENCE}

Kulm and Byrne (1966) sfate that because of the constancy of tidal and basin characteristics, the primary factor which determines the change in estuarine system is river discharge. River discharge is in turn related to precipitation. They point out that on the southern oregon coast a marked increase in precipitation in october is not reflected by an increase in runoff as shown by salinity until about a month later. This pattern is probably the same in Tillamook Bay also, but data is not available to assess at this time.

One other possible climatic control of the estuarine system is storm wave mixing. As noted before, the location and orientation of Tillamook Bay is such that prevalling winds sometimes create a wind driven chop and over large areas of the bay these waves "feel" the bottom and ald 
the mixing as well as assist in moving sand and silt sized particles.

The author observed a typical summer day with a northwest wind of about 450 meters per minute $(15 \mathrm{miles}$ per hour). This weather, within a few hours, built up a chop with a wave height of nearly one meter. These were relatively short steep waves so the wave length was on the order of six meters. These waves could easily affect the bottom at three meters and probably deeper.

\section{ESTUARINE CURRENTS}

Currents, as pointed out by Burt and McAllister (1959), are to a large degree controlled by the type of estuarine system. Some estuaries in Oregon, when we11mixed, display a slow net drift of water in a seaward direction at all depths. When partly-mixed, they show a net upstream movement along the bottom and net seaward movement on the surface. No measurements were taken in Tillamook Bay to establish the currents to see if these patterns hold true to type. The United States Corps of Engineers did attempt to measure currents in the outer channel but the equipment carried away at twelve feet per second and the United States Coast Pilot shows a current velocity of up to three knots in the channel. Inside of the bay proper no extensive and continuous measurements of currents have been made. 
$X$ PREVIOUS WORK

No previous geologic studies have been made of the bay system. However, coastal land forms including dunes and terraces are discussed by Twenhofel (1943 and 1946). Dicken (1955), Cooper (1958), Mckay (1962), Baldwin (1964), North and Byrne (1965) and Palmer (1967). Kulm, Schedegger and Splgai (1968) reported on the heavy mineral assemblages of Oregon and northern California coastal rivers. Brown, Clark and Pope (1958) describe the closure of the break of the Bayocean Peninsula and the recent erosional history of the spit. Geology of the northern Coast Range has been done by numerous workers, among them warren and others (1945) and Brown (1956). Schlicker and others (1972) describe the engineering geology and geologic hazards of rillamook and clatsop countles. 


\section{INVESTIGATIVE PROCEDURES}

\section{FIELD SAMPLING PLAN}

A rational sampling plan was made to take into account any previous information available. An initial prediction was made that sediment physical parameters are strongly dependent upon water depth, with the assumption that within the bay the deeper the water, the higher the energy or faster the current. This is assumed to be the primary controlling agent for determining particle size parameters. Sediment descriptions involving size characteristics are incomplete without an assessment of variability or variance. For a discussion of this subject as related to geology see Krumbein and Graybill (1965) and for a statistical approach see Cochran (1963). Accordingly, steps were taken to assess this factor. An initial survey was conducted and three samples were taken from 0 meters, 1 meter ( 3 feet) and 2 meters (6 feet) depths. The datum plane is mean lower low water. Lower low water is the lowest of the two daily low tides. Three grabs were taken at each station by successive lowering of the sampler. The upper 0.5 centimeter of each grab was sampled three times for analysis. The sampling scheme is a three stage nested plan and allows 
a three level nested analysis of variance program (Table I). Three level random nested models for the analysis of variance are described by Krumbein and Graybill (1965) and Cochran (1963).

Variance was analyzed using the terms shown in Table I. The analysis of variance (Table II) of the preliminary stations indicates a greater variance between stations than between samples. Ranking of variance estimates is done by comparing $F$ ratios. The higher the $F$ ratio the better one is able to discriminate between stations with that measure.

At the next level, the between-subsample variation of sorting and skewness is greater than the betweensample variation. Because of this, to increase precision of the values of percent sand, percent silt and median phi, one would increase the number of samples, not subsamples. Conversely, to increase precision on measures of sorting and skewness, one would increase the number of subs amples.

One other computation was done on the data before proceeding. Contour lines separated by $2.48 \sqrt{\sigma_{x}^{2}}$ (where $\sigma_{x}^{2}$ is the variance estimate for the station mean) can be resolved at the 90 percent confidence level and a power of 0.8 (McIntire 1963).

If $\sqrt{\sigma_{x}^{2}} \leq 0.0404$ then 0.5 phi is a reasonable contour interval for median phi. In the case of the preliminary 
TABIE I

NESTED ANALYSIS OF VARIANCE TABLE (RRELIMINARY STATIONS)

Source of Sum of Degrees of Mean Expected

Variation Squares Freedom Square Mean Square

Total $\quad 88_{\text {tot }}, \quad 26$

Among

Stations

SB

2

MS sta $\sigma_{\text {sub }} \quad 2 \sigma_{\text {sam }} \quad 4 \sigma_{\text {sta }}$

Among

Samples

Within

Stations

S8 8 am

6

$\mathrm{MS}_{\text {sam }} \sigma_{\text {sub }} 2 \sigma_{\text {sam }}$

Among

Sub-

Samples

within

Grabs

SE sub

18

${ }_{\text {sub }} \sigma_{\text {sub }}$ 
TABLE II

ANALYSIS OF VARIANCE STATISTICS (PRELIMINARY SAMPLES)

\begin{tabular}{lrrrr} 
SV & DF & SS & MS & Percent Sand \\
\hline \multicolumn{5}{c}{} \\
Station & 2 & $15,468.08$ & 7.734 .04 & 210.30 \\
Sample & 6 & 220.66 & 36.78 & 1.34 \\
Subsample & 18 & 495.33 & 27.52 & \\
Total & 26 & 16.184 .08 & & \\
\hline
\end{tabular}

\section{Percent silt}

$\begin{array}{lrrrr}\text { Station } & 2 & 10.170 .29 & 5.085 .16 & 188.34 \\ \text { Sample } & 6 & 162.00 & 27.00 & 1.83 \\ \text { Subsample } & 18 & 266.00 & 14.78 & \end{array}$

Total

26

$10,598.30$

Median Phi

$\begin{array}{lrrrr}\text { Station } & 2 & 32.24 & 16.12 & 297.42 \\ \text { Sample } & 6 & 0.33 & 0.05 & 2.12 \\ \text { Subsample } & 18 & 0.46 & 0.03 & \end{array}$

Total

26

33.03

\section{Sorting}

\begin{tabular}{lrrrr} 
Station & 2 & 14.18 & 7.09 & 46.29 \\
Sample & 6 & 0.92 & 0.15 & $<1.0$ \\
Subsample & 18 & 3.93 & 0.22 & \\
& & 19.04 & & \\
Total & 26 & & & \\
\hline
\end{tabular}

Skewness

$\begin{array}{lrrrr}\text { Station } & 2 & 156,586.69 & 78,293.34 & 13.01 \\ \text { Sample } & 6 & 36,104.01 & 6,017.33 & <1.0 \\ \text { Subsample } & 18 & 289,657.37 & 16,092.07 & \\ \text { Total } & 26 & 482,348.07 & & \end{array}$


samples $\sqrt{\sigma_{x}^{2}} \quad 0.04$ indicating that a $0.5 \mathrm{phi}$ contour interval is the closest that can be justified (see Table III).

Compared to other published work, the level of precision calculated for the preliminary samples in Tillamook Bay seems very poor. Contouring of median phi at 0.1 phi is frequently seen in the literature. None of the 11terature examined by the author, where median phi was contoured at close intervels, included any refexence to the method used to determine contour interval. One study did caloulate contour Interval (Kelly and Mc Manus 1969) and used the relatively large interval of 0.75 phi units. It is probable that contouring at close phi intervals is frequently done on the basis of intuition rather than computation. High levels of variance that do not allow close interval contouring, such as found in Tillamook Bay, could cause the suspicion that the analysis is not being done with enough accuracy. For this reason, one sample was reanalyzed and the variance for median phi estimated. This estimate was 0.21 and is in close agreement with other reported estimates as being what one could expect for experimental error (Krumbein 1934). Kelly and MaManus (1969) report that sediments of the North Pacific shelf off the coasts of Oregon and Washington are variable enough to require three samples per station and three subsamples per sample 
TABLE III

F RATIOS AND BETWEEN STATION MINIMUM RESOLVABLE

DIFFERENCES FOR GRANULOMRTRIC VARIABIBS

(PRELIMINARY SAMPLES)

\begin{tabular}{|c|c|c|c|}
\hline Variable & $\mathbf{F}_{1}$ & $\mathbf{F}_{2}$ & MRD \\
\hline Percent sand & 210.36 & 1.34 & 5.31 percent \\
\hline Percent silt & 188.34 & 1.83 & 6.29 percent \\
\hline Median phi & 297.42 & 2.12 & $0.51 \mathrm{ph} 1$ \\
\hline sorting & 46.29 & 0.70 & 0.17 \\
\hline Skewness & 13.01 & 0.37 & 11.16 \\
\hline$F_{1}=\frac{M S \text { among }}{\text { MS among }}$ & $\frac{\text { stations }}{\text { s amples }}$ & & \\
\hline$F_{2}=\frac{M S \text { among }}{M S \text { among }}$ & $\frac{\text { samples }}{\text { subs amples }}$ & & \\
\hline
\end{tabular}


to obtain enough precksion to contour median phi at the 0.5 phi interval. This is based on a within-station variance of 0.22 for sediments on the North Pacific shelf. On the basis of the foregoing preliminary data analysis the following sampling system for the bay was developed. The design of the sampling plan is determined by the degree of precision desired and the cost of obtaining and analyzing samples and subsamples. The major factor in the design was cost, including time. It was decided that a maximum of one hundred sets of data could be analyzed and samples or subsamples were equally costly.

It was also decided to stratify the bay into populations based on water depth since water depth is considered an indicator of sedimentary environment. These populations are a 2 meter population from -1 meter to -3 meter, the 4 meter population from -3 meter to -5 meter, and so forth. The depths are based on a zero datum of mean lower low water. Because of the possibility of some of the granulometric measures varying systematically from the mouth to the head of the bay, samples were taken at regular intervals from north to south. The final sampling plan is as follows: The entire bay was divided into populations based on water depth and each population was sampled systematically along the northsouth axis of the bay. The stations were sampled twice 
and the samples were not subsampled.

This final sampling plan cannot be defined as random, because the samples from each population were taken in a systematic, not random manner, so the statistics describing attributes of a population or the bay as a whole must be used with caution.

Sediments were collected from thirty-five locations In the bay plus some additional samples from nearby beachen, dunes and from the rivers feeding the bay (Figure 2). Samples were collected from a nineteen foot skiff with a small crane system installed to lower and retrieve the sampler. The sampler was a United states Geological Survey grab sampler type BM 54 (Figures 4a and 4b), which takes a half cylindrical sample of about 500 cuble centimeters, depending on depth of penetration. The sampletaking apparatus is housed in a streamlined cast iron housing which weighs approximately 70 pounds. The weight and streamlined shape allow the samplex to operate in quite high currents without tipping or failing to reach the bottom. This feature is quite valuable in estuaries as current strengths can be considerable.

The trip system on the sampler required that most of the weight be off the cable to operate the release and take the sample. Because of this, samples taken in soft mud might not be surface samples since the sampler might sink into the mud before activating. The sampler did 


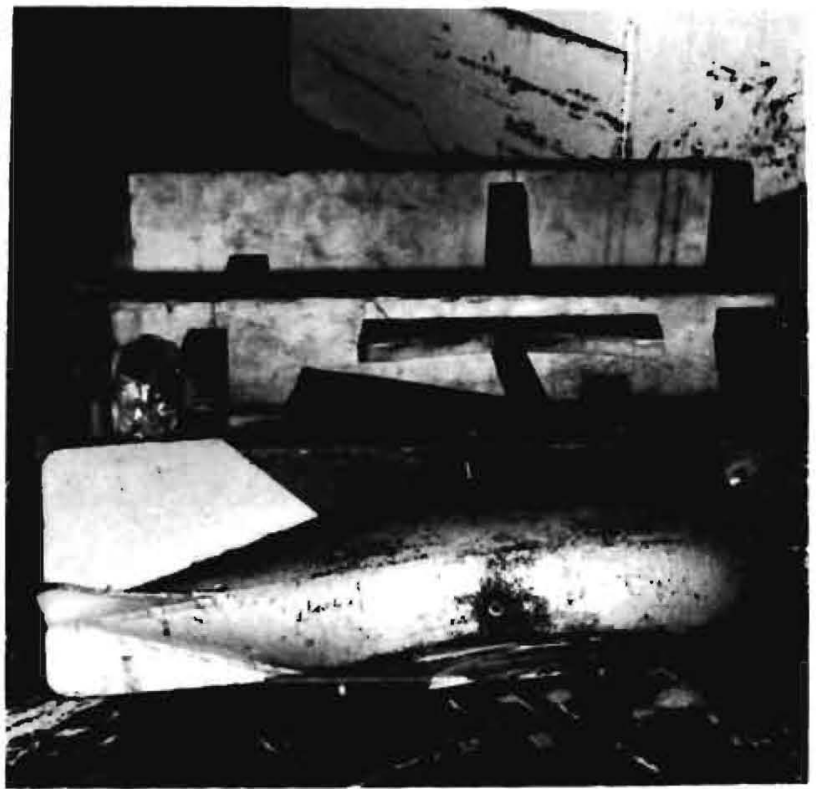

Flgure 4a. B. M. 54 sampler ready to take sample.

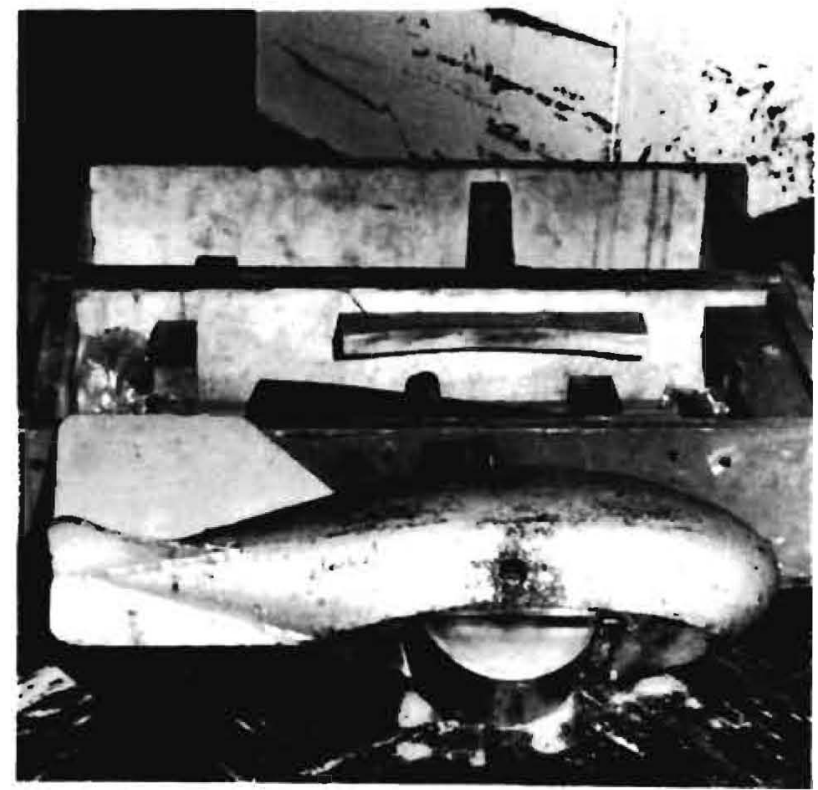

Figure 4b. B. M. 54 sampler after taking sample. 
seem to preserve sediment orientation and every effort was made to transfer samples from the sampler to the storage container without destroying this orientation.

With sample orientation preserved, only the top layer was removed for analysis in the hope that only one sedimentation unit would be sampled.

Sampling was completed during August of 1971. . It is believed that the time involved was short enough that no significant changes occurred in the sediments of the bay during the sampling period.

\section{TEXTURAI ANAIYSIS}

Samples were kept in a moist state and no disaggregation was done in an attempt to maintain the sediment in its natural state. To obtain the material from the sample for analysis, approximately 25 cubic centimeters was carefully removed from the top of each sample. Every effort was made to analyze only one sedimentation unit (Otto 1928), however, it is believed that this was not always successful. The inability to examine a single sedimentation unit, as will be noted later, causes difficulty in interpreting the results of the granulometric analysis.

The 25 cubic centimeters from each sample was wet sieved through a 63 micron sieve. The coarser-than 63 micron fraction was dried and sieved in a Ro-Tap. The 
finer than 63 micron fraction was analyzed by pipette. The resulting data were combined for plotting on graph paper.

\section{HEAVY MINERAL ANALYSIS}

Heavy minerals were separated from selected samples by using tetrabromoethane which has a specific gravity of 2.96 at $20^{\circ} \mathrm{C}$. After removal of the magnetic fraction with a hand magnet, the remainder was ground in a mortar to -200 mesh. This powder was mixed with Duco cement as a slurxy and mounted on petrographic microscope slides for X-ray diffraction (Pryor and Hestor 1969). The mounted samples were irradiated at a scan rate of $4^{\circ} 2 \theta$ per minute from $10^{\circ}$ to $50^{\circ} 2 \theta$. The purpose of this technique is to provide an X-ray diffraction "fingerprint" of the heavy mineral assemblage, not to identify individual heavy minerals. The technique provides a rapid method of comparing the heavy mineral assemblage of any two locations.

\section{CLAY MINERAL ANALYSIS}

Two samples of the less than 2 micron suspended sediment from the bay were mounted for electron microscope observation. To make the mount for observation, a thin layer of polyvinyl chloride was placed on a 200 wire per inch copper grid. A drop of the sample suspension was 
put on the grid with a pipette and allowed to dry. The sample was then placed in a high vacuum chamber and a thin layer of carbon was evaporated over the sample. The samples were then placed in the microscope for observation.

\section{GRANULOMETRY}

\section{Analysis of Variance}

To obtain the data for analysis, the size characteristics of the sediments were plotted on probability graph paper. The measures used, percentage of sand, percentage of silt, median phi, sorting and skewness, were derived graphically. Sorting and skewness used are the Inclusive graphic standard deviation $\left(\sigma_{I}\right)$ and Inclusive graphic skewness $\left(S k_{I}\right)$ of Folk (1968). Where $\sigma_{I}=$ $\frac{\not 84-\not 16}{4}+\frac{\not 95-\not 55}{6.6}$ and $s_{I}=\frac{\not 16+\not 88-2 \not 50}{2(\varnothing 84-\varnothing 16)}+$ $\frac{\not 5+\not 95-2 \not 50}{2(\not 95-\not 5)}$. These two statistics are not totally independent and when using graphic measures they are not completely independent of the median. Consequently, caution should be used when interpreting these statistics.

Analysis of variance was computed using the hierarchy in Table IV. Computations for the variance analysis were done on an IBM 1130 computer. The results for the bay as a whole are summarized in Table V. Ranking the $F$ values shows that median phi is the measure most capable of discriminating between stations 
TABLE IV

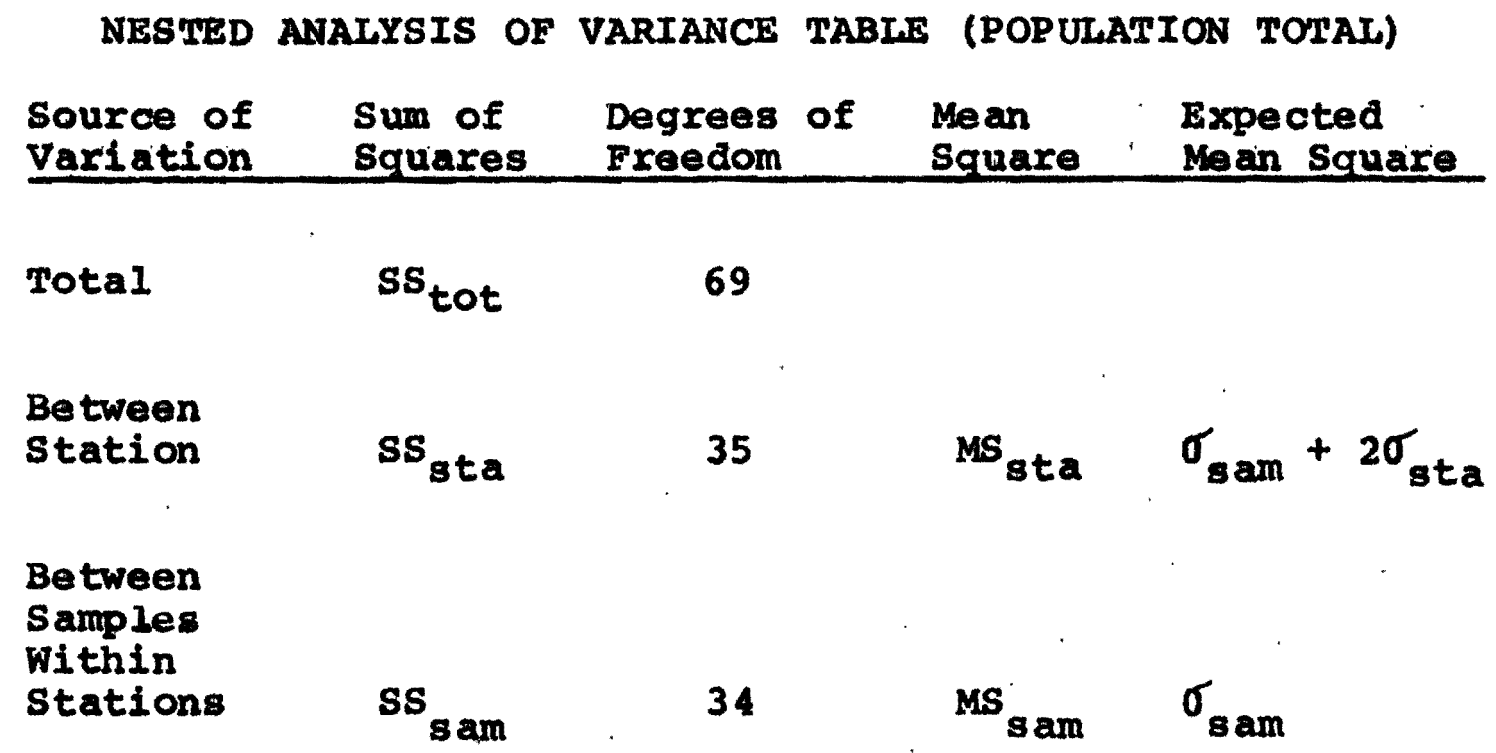


TABLE V

ANAIYSIS OF VARIANCE STATISTICS (POPULATION TOTAL)

\begin{tabular}{llcll} 
SV & DF & SS & MS & F \\
\hline Station & 34 & Percent Sand & & \\
Sample & 35 & 33.253 .16 & 978.03 & 6.92 \\
Total & 69 & 4.943 .50 & & \\
& & 38.196 .66 & & \\
Station & 34 & 30.467 .37 & & \\
Sample & 35 & 4.265 .50 & & \\
Total & 69 & 34.732 .87 & \\
\hline
\end{tabular}

Median Phi

$\begin{array}{lrrrr}\text { Station } & 34 & 52.93 & 1.56 & 8.73 \\ \text { Sample } & 35 & 6.63 & 0.19 & \\ \text { Total } & 69 & 59.55 & \end{array}$

\section{Sorting}

$\begin{array}{llrrr}\text { Station } & 34 & 16.52 & 0.486 & 3.59 \\ \text { Sample } & 35 & 4.74 & 0.135 \\ \text { Total } & 69 & 21.26 & & \end{array}$

\section{Skewress}

$\begin{array}{lllll}\text { Station } & 34 & 5,433,242.01 & 159,801.22 & 4.50 \\ \text { Sample } & 35 & 1,242,734.25 & 35,506.69 & \\ \text { Total } & 69 & 6,675,976.26 & & \end{array}$


within the populations. Skewness has a higher $F$ ratio than sorting; this is reversed from the preliminary sample data.

The column labeled MRD (Minimum Resolvable Difference) in Table VI is the minimum value that will give an appropriate T-test at the 90 percent confidence level. For the total population, as shown with the preliminary data, using median phi as an example, one can distinguish between two stations if $D=(2.612)\left(\sqrt{\sigma_{x}^{2}}\right)$ where $\sigma_{\mathbf{X}}^{2}$ is the estimator of the station variance and $D=$ difference. Inserting the appropriate value and computing for D shows that the minimum resolvable difference for median phi is 0.80 phi units. Accordingly, median phi was contoured at a 1 phi interval (Figure 5). The reasons for choosing 1 phi rather than 0.8 phi are a desire for simplification in the display and a feeling that contours labeled $0.8,1.6,3.4$, and so forth, would create the mistaken impression that the figure is, significant at 0.1 phi units.

Even though the minimum resolvable difference is not a very powerful statistic, it was chosen in order to allow some geologic interpretation. A much more powerful statistic would be the minimum significant difference of the Tukey method (Sheffe 1959). This test yields values of nearly 2 phi for median phi and values with this order of magnitude for the other measures also. 


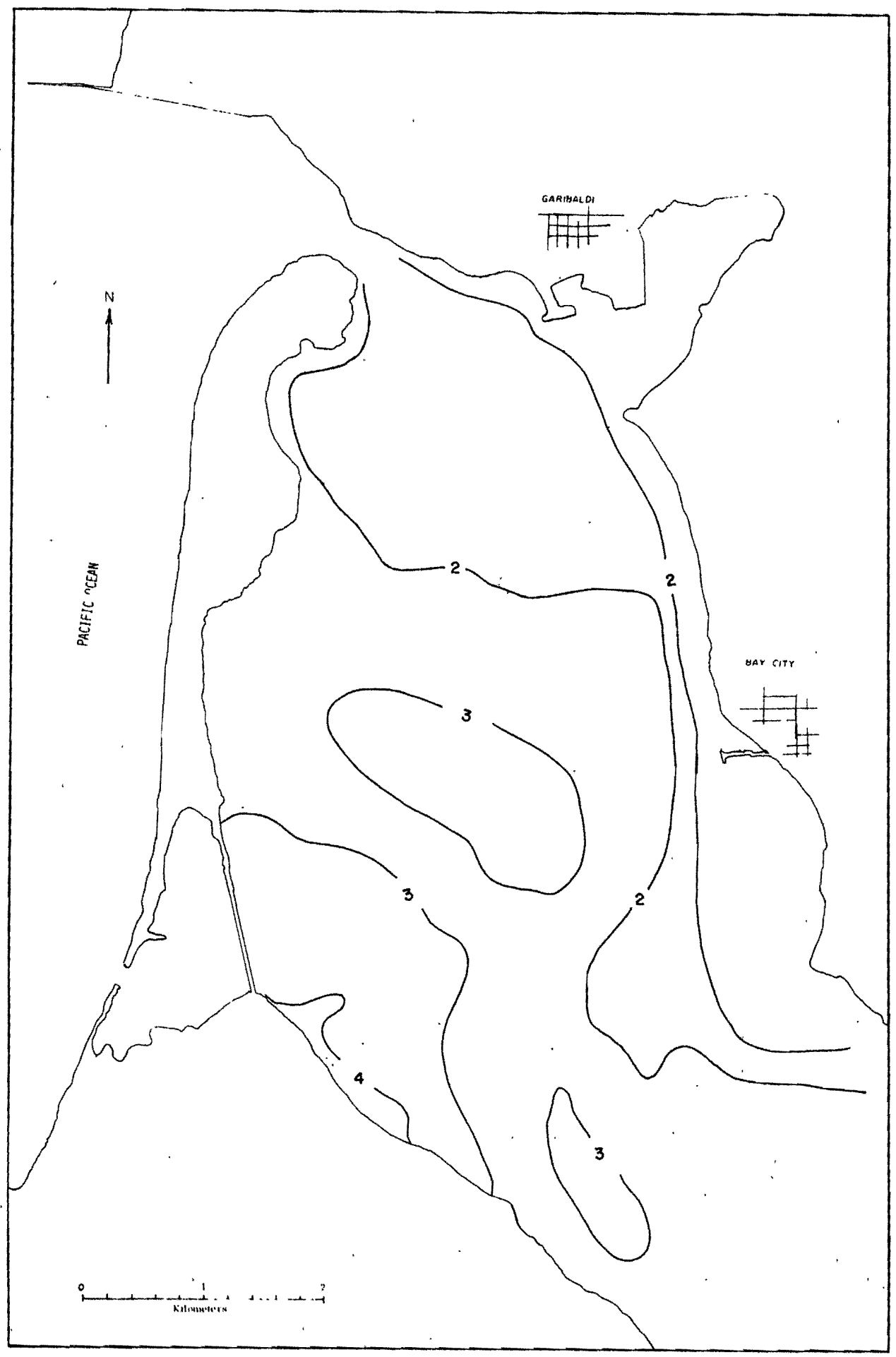

Fiqure 5. Distribution of median grain size of sediments in Tillamook Bay. Contour interval 1 phi. 
The minimum significant difference means that while it is possible to distinguish between two stations in Tillamook Bay which differ in median phi by $0.8 \mathrm{phi}$, there really is no significant difference unless the stations are separated by at least 2 phi. Interpretations using the Tukey test are almost impossible but the implications of minimum significant difference versus minimum resolvable difference should not be overlooked.

Looking at Figure 5, a strong linear trend can be seen, with a coarser median size found to the north and finer to the south. This indicates that in summer, when the study was conducted, higher average energies are present in the northern part of the bay than in the southern part. Higher energy should be expected in the northern part of the bay during the winter, too.

The minimum resolvable difference for percentage of sand and percentage of silt was calculated also. Table VI shows the variance for both these measures to be quite high. The percentage of sand, silt and clay was plotted on Figure 6, using the classification of Folk (1968). When viewing this areal distribution of sediment type, it should be remembered that some of the boundaries cannot be justified at the 90 percent confidence level. This figure was included because even with its limitations it, in some ways, displays sediment type better than median grain size. Median grain size and sediment type 


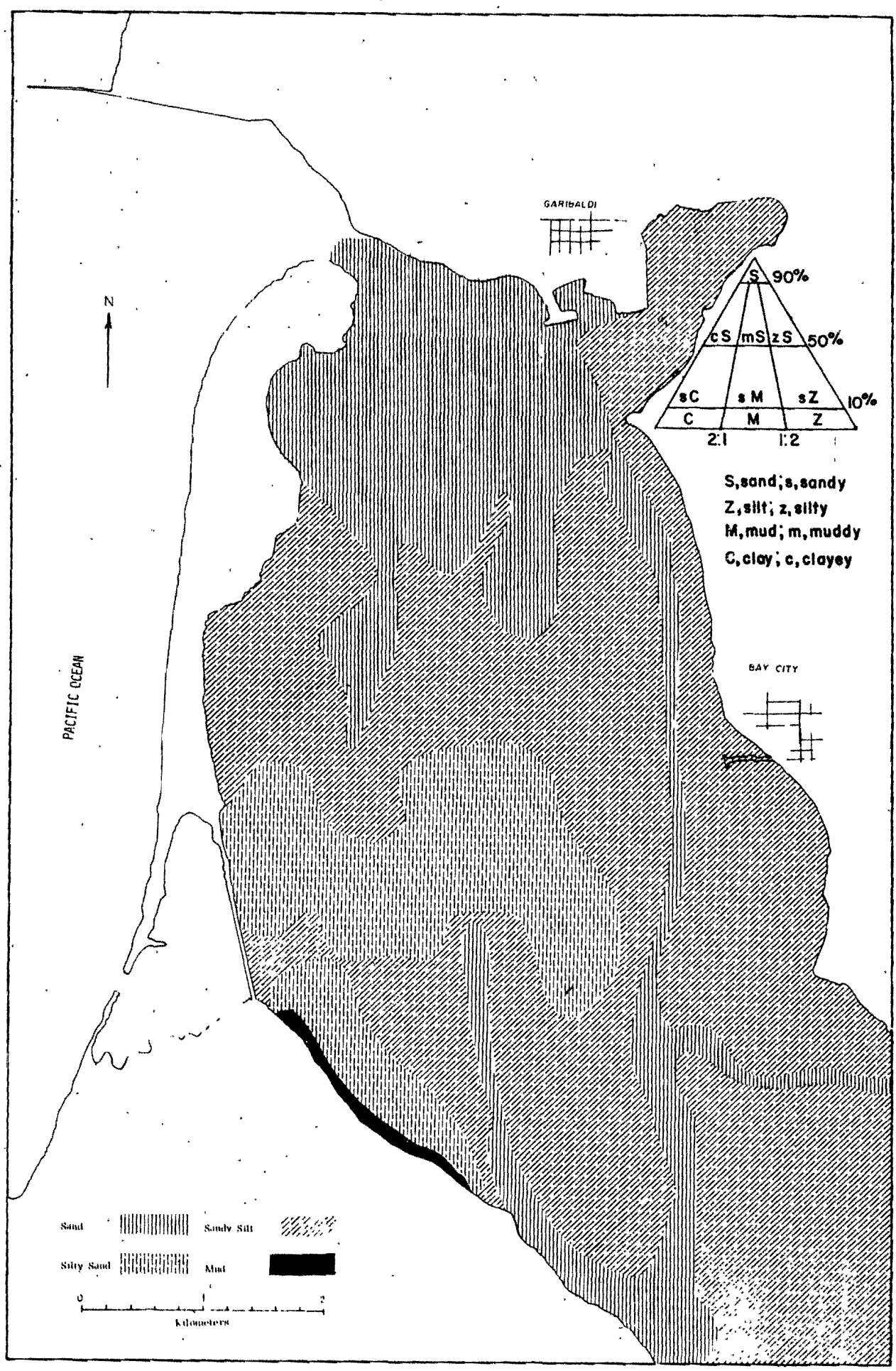


are not necessarily correlated. A very well sorted sediment with a median size of 4.5 phi could be classified as silt and poorly sorted sediment with the same median size of 4.5 phi could be a sandy mud. The pattern in the western central part of the bay (zS) is partly a result of sand being washed into the bay when the spit was breached in 1952. A pattern of sand can be seen in the primary drainage channels in the bay.

Skewness and sorting

Skewness and sorting showed areal patterns, accordingly these parameters were contoured into major subdivisions (Figure 7).

Samples from the few coarse skewed areas were plotted on a CM diagram (Passega 1957) (Figure 8). All of these samples plotted in the beach deposit field. Friedman (1967) and Passega (1957 and 1964) both indicate a beach deposit should be relatively free of "fines" or skewed to the coarse. All of the areas with coarse skewed sediments are areas of cut or erosion (Figure 3). It seems quite likely that erosion has, in these areas, exposed a previously covered beach deposit from an earlier time.

A CM diagram is a plot of the size class containing the coarsest 1 percentile (C) versus median grain size (M). The value $\mathrm{C}$ is representative of the minimum 


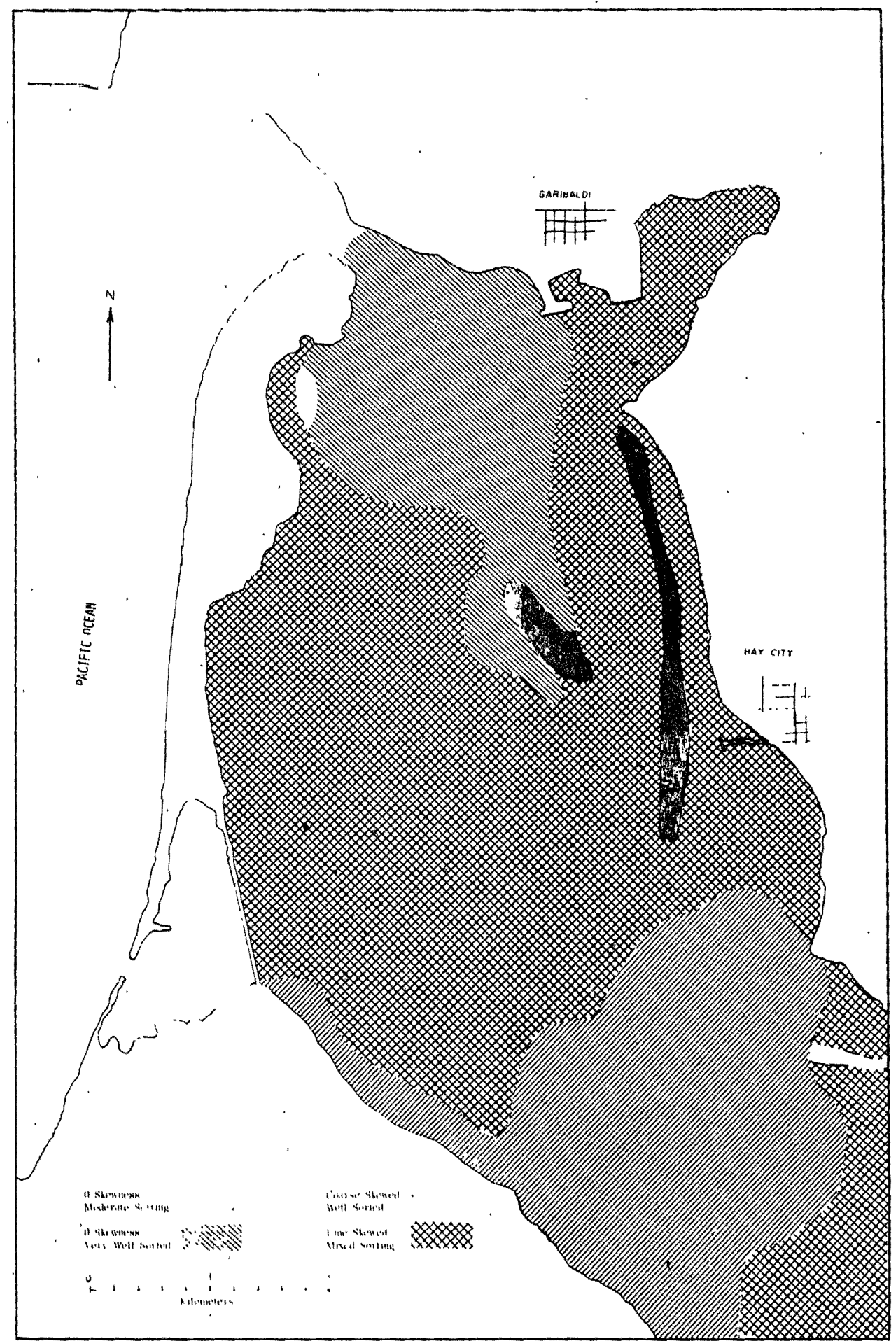

Figure 7. Distribution of skewness and sorting ot seaiments in Tillamook Bay. 


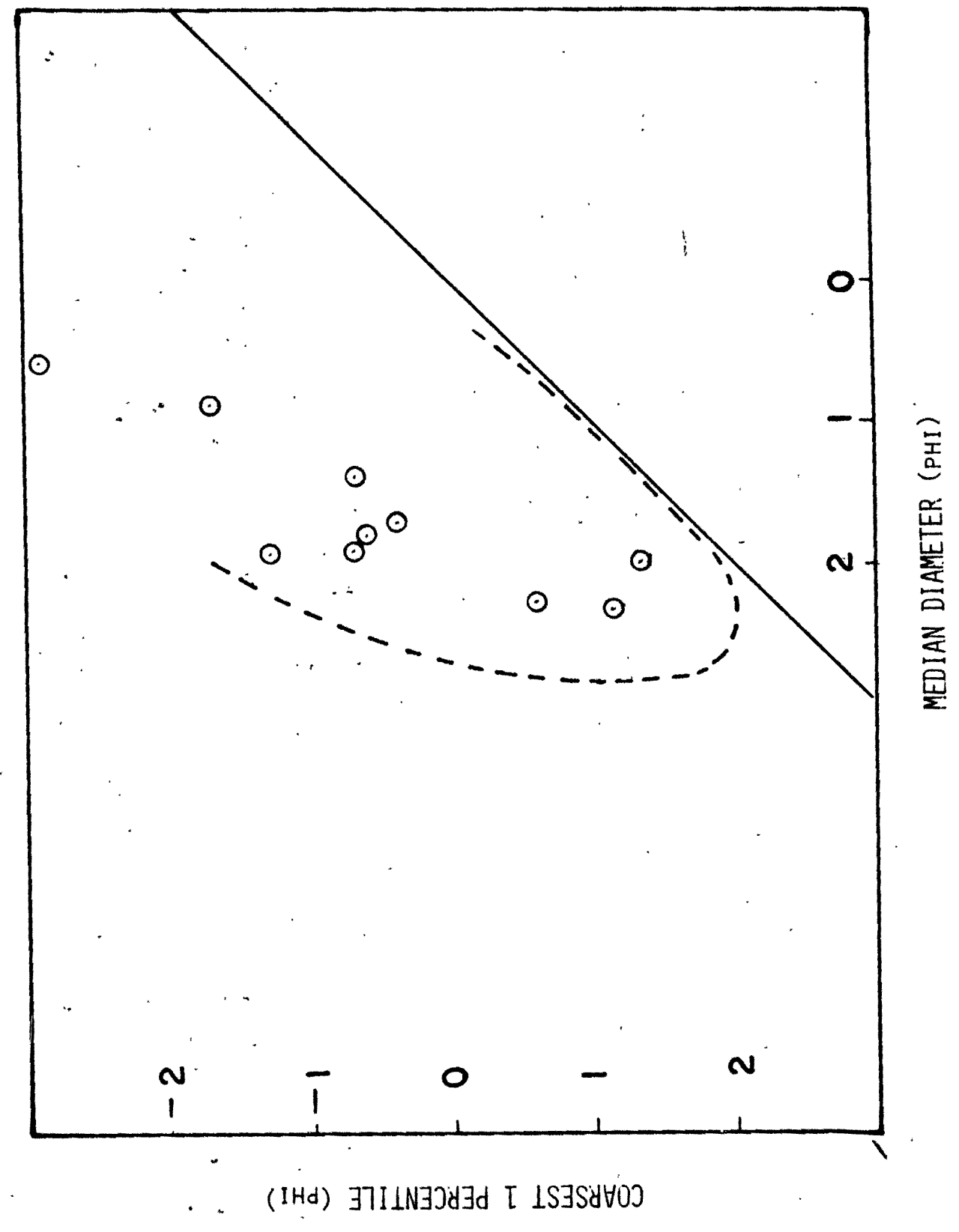

Figure 8. Plot of the coarsest 1 percentile versus median grain size for those stations that were skewed to the coarse. All stations plot in the beach field of Passega. (after Passega 1957) 
competence of the transporting medium and $M$ is representative of the range of particles being transported. Few workers have utilized $\mathrm{CM}$ relationships to interpret environments of deposition and transport. Bull (1962) used $\mathrm{CM}$ patterns in analyzing alluvial fan deposits and Royse (1968) indicated a general validity and usefulness of CM relationships but felt wider testing necessary. The area of 0 skewness, very well sorted, in the northern part of the bay is an area of high sand percentage (Figure 6). Samples from this area plot on a CM diagram in and around the tractive current or bed load field on the diagram. Currents in this part of the bay can be quite high and, as they are primarily tidal, flow in two principal directions. Sedimentation in this area can be considered to be dominantly marine with tidal currents the major factor in determining sediment type. The 0 skewness, moderately sorted, area in the southern part of the bay seems to be largely an area that is quite shallow and is frequently exposed at lower tides. Because of this, wave stirring and carrying away of fines is reduced. If this were not the case, it would be expected that the sediment would be skewed to the coarse as wave action can be considerable in the southern part of the bay in the summer. Qualitative observation of near surface water in this area during sampling indicated that the water can be quite turbid. The sampler 
frequently could not be seen deeper than one meter.

The central part of the bay with fine skewness and mixed sorting seems to be a transition zone between the north and south. Mixed sorting in this case means sorting that ranged from well sorted to poorly sorted with no areal pattern evident. This central part of the bay is where the majority of flora and fauna likely to influence sedimentation are found. Large areas of eelgrass, zostera, are found in this part of the bay. The grass functions as a trap for fines by locally reducing current velocity. This same central area also supports a large burrowing animal population. Some noted by the author were: cockle, Clinocardium, gaper or horseneck clams, Schizothaerus nuttallii, softshell clams, Mya arenaria, and sand shrimp, Upogebia pugettensis, to name a few. In some areas it was apparent that bioturbation was such that no stratification remained in the sediments. In these areas no undisturbed surface could be seen; the entire surface was either material thrown up around a burrow or the hole itself.

\section{Subpopulation Statistics}

Table VII is a summary of the pertinent statistics developed when the bay was divided into populations defined by water depth. The table shows mean square, F ratio, and minimum resolvable difference. When 
TABLE VI

F RATIOS AND BETWEEN STATION MINIMUM RESOLVABLE DIFFERENCES FOR GRANULOIETRIC VARIABLES (TOTAL POPULATION)

Variable

Percent sand

Percent silt

Median phi

sorting

Skewness
E

$$
6.92
$$

7.35

8.23

3.59

4.50
MRD

21.95 percent

20.37 percent

$$
0.80 \text { phi }
$$

$0.68 \mathrm{phI}$

0.35 
TABLE VII

F RATIOS AND BETWEEN STATION MINIMUM RESOLVABLB DIFFERENCES FOR GRANULOMETRIC VARIABLES

(SUBPOPULATIONS DEFINED BY WATER DEPTH)

\begin{tabular}{|c|c|c|c|}
\hline & MS & $F$ & MRD \\
\hline \multicolumn{4}{|c|}{ - 2 Meter Depth } \\
\hline $\begin{array}{l}\text { Sand } \\
\text { Silt } \\
\text { Median Phi } \\
\text { Sorting } \\
\text { Skewness }\end{array}$ & $\begin{array}{r}34.00 \\
98.50 \\
0.13 \\
1.30 \\
76.74\end{array}$ & $\begin{array}{r}54.72 \\
35.34 \\
26.29 \\
0.03 \\
30.69\end{array}$ & $\begin{array}{l}15.55 \\
26.48 \\
0.95 \\
0.96 \\
0.07\end{array}$ \\
\hline \multicolumn{4}{|c|}{ O Meter Depth } \\
\hline $\begin{array}{l}\text { Sand } \\
\text { Silt } \\
\text { Median Phi } \\
\text { Sorting } \\
\text { Skewness }\end{array}$ & $\begin{array}{r}42.94 \\
25.06 \\
0.06 \\
0.13 \\
39.02\end{array}$ & $\begin{array}{r}27.70 \\
40.65 \\
30.49 \\
4.13 \\
3.62\end{array}$ & $\begin{array}{r}12.43 \\
9.49 \\
0.45 \\
0.66 \\
0.37\end{array}$ \\
\hline
\end{tabular}

2 Meter Depth

$\begin{array}{lrrr}\text { Sand } & 268.29 & 1.68 & 31.56 \\ \text { Silt } & 219.87 & 1.50 & 28.59 \\ \text { Median Phi } & 0.44 & 2.11 & 1.28 \\ \text { Sorting } & 0.13 & 3.80 & 0.70 \\ \text { Skewness } & 24.19 & 7.04 & 0.30\end{array}$

4 Meter Depth

$\begin{array}{lrrr}\text { Sand } & 193.80 & 1.37 & 29.07 \\ \text { Silt } & 205.80 & 1.06 & 29.93 \\ \text { Median Phi } & 0.03 & 1.62 & 0.36 \\ \text { Sorting } & 0.17 & 2.72 & 0.87 \\ \text { Skewness } & 34.93 & 10.04 & 0.39\end{array}$


comparing this data with that found in Table $V$ and Table VI, some strong differences are noted. Looking at $F$ ratio rank we find in the population as a whole, sorting and skewness are the two poorest statistics for discriminating between stations. However, in the 2 meter (6 feet) and 4 meter (12 feet) populations these are the best measures. Median phi in all the depth populations seems to hold constant in F ratio ranking while the percentages and the higher moments trade about. When looking at the minimum resolvable difference no significant gain in minimum resolvable difference can be seen at any depth population when compared to the population as a whole.

\section{Cumulative Curves}

The statistics, median phi, sorting and skewness, are at their best when used to describe curves or distributions that are normal or nearly normal. As the distribution departs from normal, the statistics do an ever poorer job of describing the distribution. In the case of the sediments in Tillamook Bay, some station granulometric data are very near normal while others depart from normal significantly. The author has subjectively divided the cumulative size frequency curves into three classes or types. These types are shown in Figure 9 as found in Tillamook Bay. 


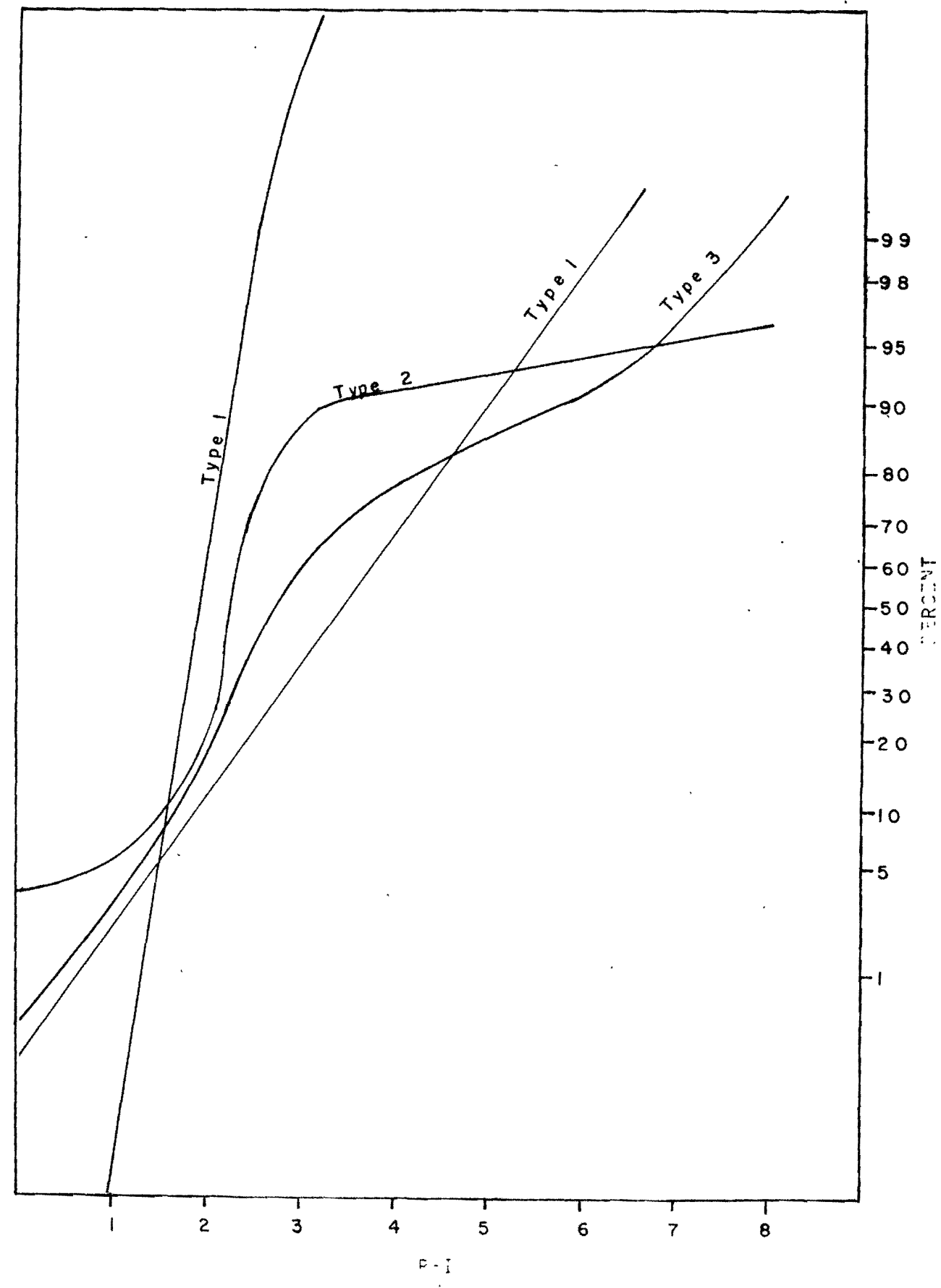

Figure 9. Sediment cumulative curve types in Tillamook Bay. Type 1, straight or normal. Type 2, s curved. Type 3 , humped. (Probability ordinate) 
The curves are drawn with probability as the ordinate and phi units on the abscissa. With these scales a straight line would be a normal distribution and the slope of the line would indicate standard deviation or sorting. The visual appearance of these curves almost compels one to think of attempting to describe the curves as mixtures of two or more normal curves. Type 2 curves are frequently found with the lower part of the $s$ truncated giving an inverted I shape. These truncated type 2 curves seem to be a combination of two normal populations, one being a well sorted sand and the other a poorly sorted mud.

Type 3 curves seem a little more complex. If each change in slope represents a mode then these curves are polymodal and truncated type 2 curves are bimodal.

An attempt was made to synthesize a type 2 curve. On the basis of intuition, a mixture of 70 percent well sorted sand, median phi 1.5, and 30 percent poorly sorted mud, median phi 5.5, was combined mathematically. The resulting curve, Figure 10 , is not a totally satisfactory match, but is close enough to show the method has promise. Muller (1966) and Oser (1972) have successfuliy synthesized curves of this type by using an analog computer. It would seem that a digital computer could be programmed to do this type of problem, also. 


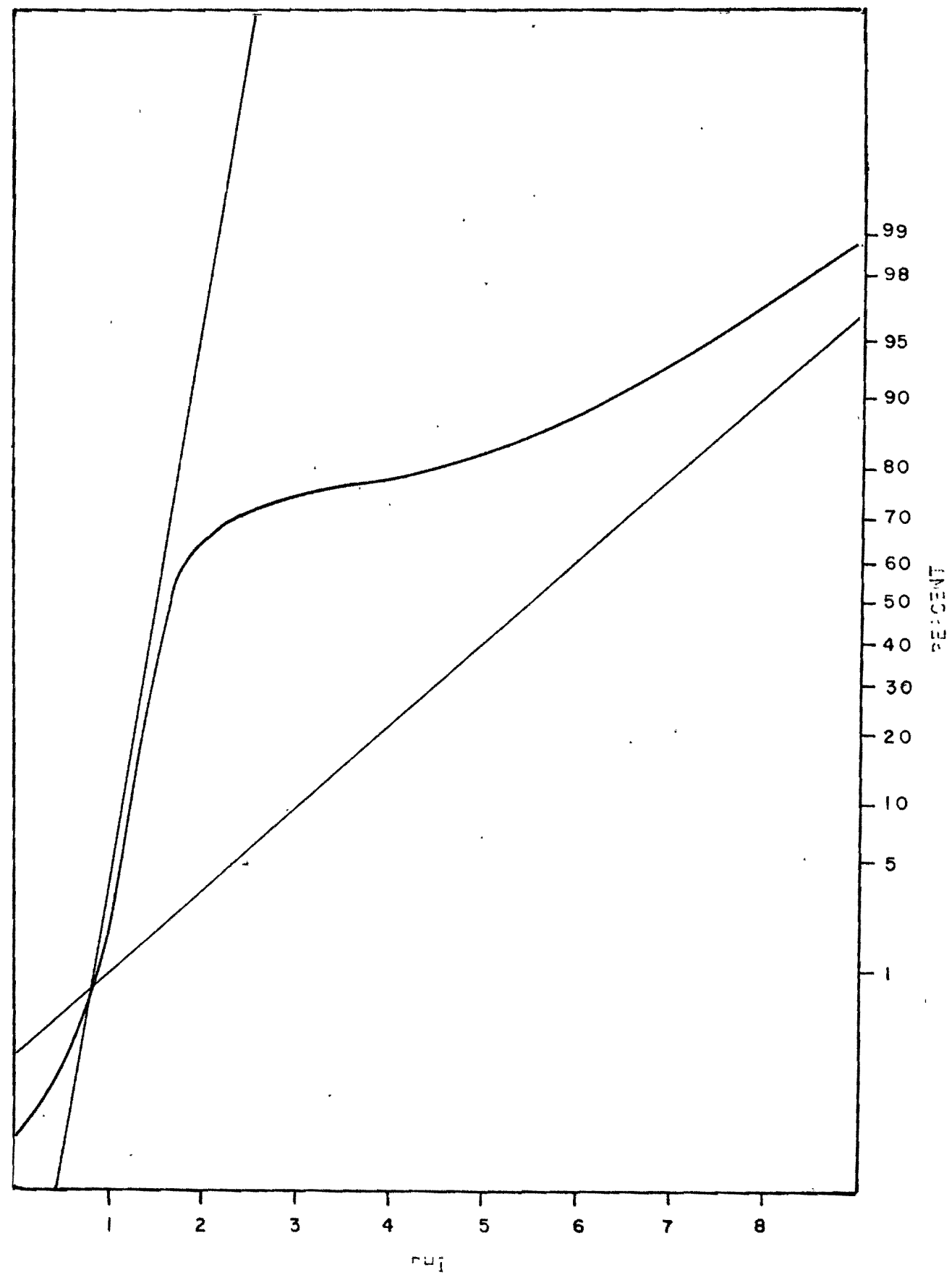

Figure 10. Synthesized curve derived from "two normal curves. The normal curves are the straight lines. The S shaped curve. is the composite of the two normal curves. 
The geologic significance of polymodal sediment distributions has been discussed by several authors. Pettijohn (1957) summarizes most of the ideas. They can be stated as follows:

1. Sediments naturally tend to have a bimodal distribution. (Udden 1914)

2. Fines have a tendency to infiltrate into interstices of a previous deposit. (Fraser 1935 and Plumley 1948)

3. Incomplete mixing of two sediments by a transporting agent results in bimodality. (Swensen 1941 and Rittenhouse 1943)

4. Faulty sampling procedure resulting in sampling two different units could also result in bimodality. (Bagnold 1941)

More recently Visher (1969) has suggested that each mode could represent a different method of transport; the coarse mode, traction or bed load; the intermediate mode, saltation; and the fine mode, suspension. Not all samples contain all three modes and some samples contain more than one mode in an area representing one type of transport.

Visher does not attempt to synthesize his curves and because of this fails to point out the influence of one subpopulation on the shape of the total cumulative curve. For instance, changing the amount of the fine or suspended 
population will change the shape of the traction and bed load parts of the curve.

Sonu (1972) found that beach sediments have two unimodal populations associated with winter and summer beach profiles. The beach sediments become bimodal as the profile changes from summer to winter with winter and summer modes evident. The process continues until the winter mode is the only one present, then reverses itself until summer.

Most of the stations that have a well sorted type 1 (one population) curve are in the northern part of the bay. It seems that the current energy is quite high here (up to 1.5 meters per second) and the entire curve represents saltation material. The other locations have curves that are complex enough to require separation of each mode to analyze.

It is the author's opinion that in Tillamook Bay the causes of polymodality in the sediments are the differences in energy of the transporting medium as well as different modes of transport for the sediment at any given energy. Further, by isolating each mode it should be possible to determine which factors are responsible at each location. To further aid the geologic interpretation, mineralogy of each population should be investigated. This could be done by examination 
of that size class containing the median of the population to be studied.

The existence of more than one normal population in the cumulative curve also leads to the idea that the high variance noted earlier is a reflection of different amounts of each population in each sample. Separation into constituent populations before describing them statistically should reduce the variance to a very low level.

VI MINERALOGY

Heavy Mineralogy

The results of the X-ray diffractions of whole heavy mineral fractions are shown in Figure 11 and Figure 12. Figure 11 shows the diffraction patterns from samples in the northern part of Tillamook Bay with the top pattern representing the Miami River assemblage and the bottom two patterns beach and older dune "fingerprints." The beach and older dune samples were collected from the beach and dune of the northern part of the spit. The intervening traces are from northern bay samples arranged in geographic sequence, east at the top, west at the bottom. Traces are easier to compare by placing the full size patterns over each other on a light table.

Some of the samples were irradiated at a slower scan rate of $2^{\circ} 2 \theta$ per minute. These traces show considerably 


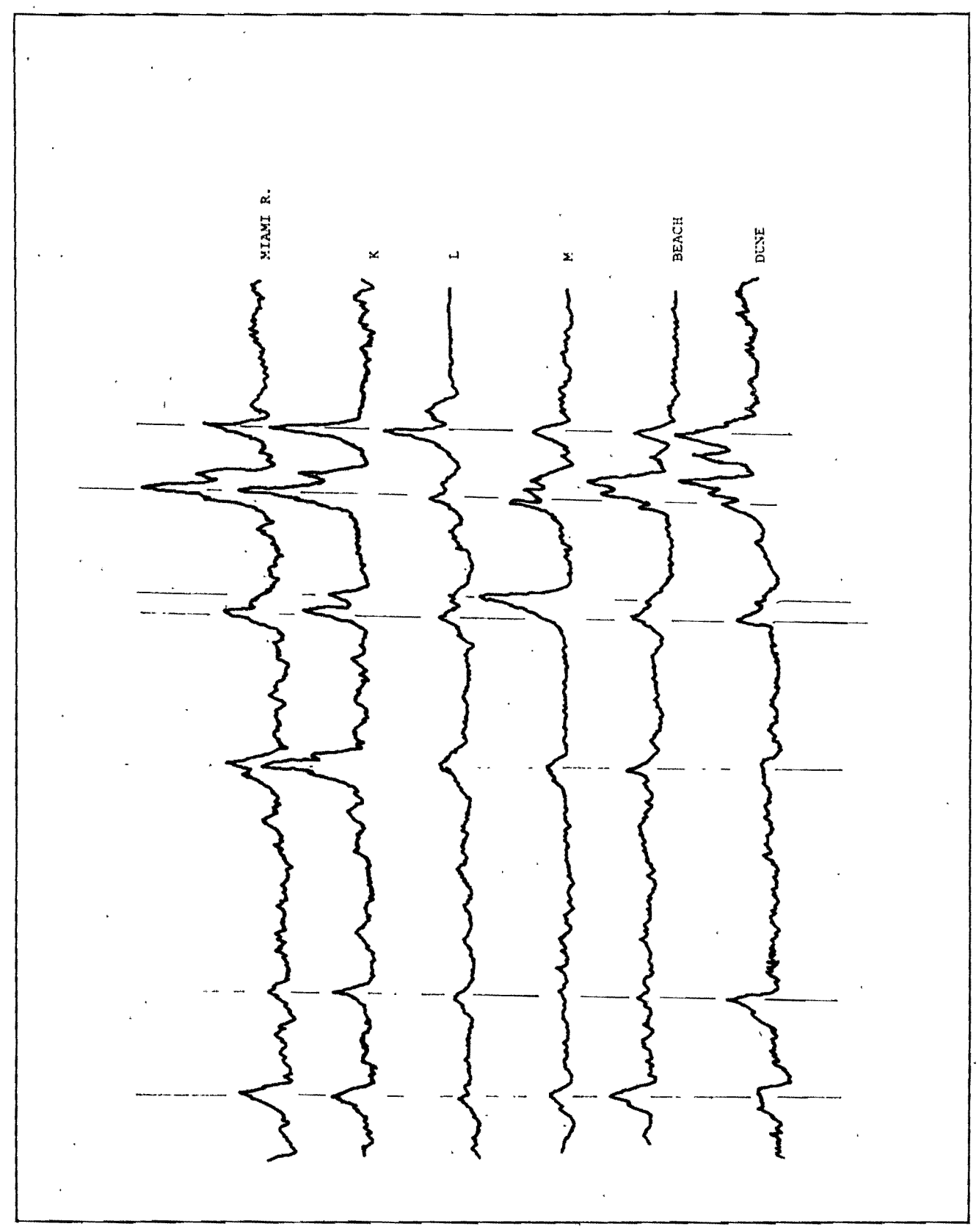

Figure 11. X-ray diffraction "fingerprints" of heavy mineral samples from the northern part of Tillamook Bay. The easternmost locations are at the top and westernmost at the bottom. 
50
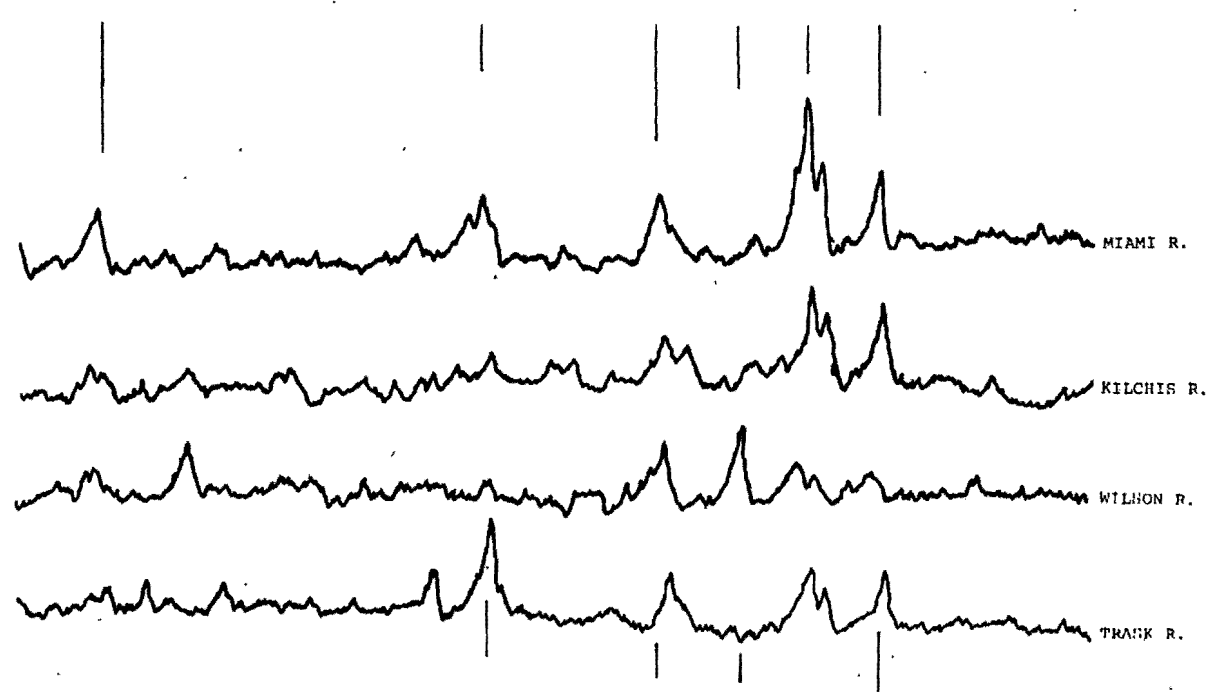

Figure 12a. X-ray diffraction "fingerprints" of heavy mineral samples from four rivers that flow into Tillamook Bay.
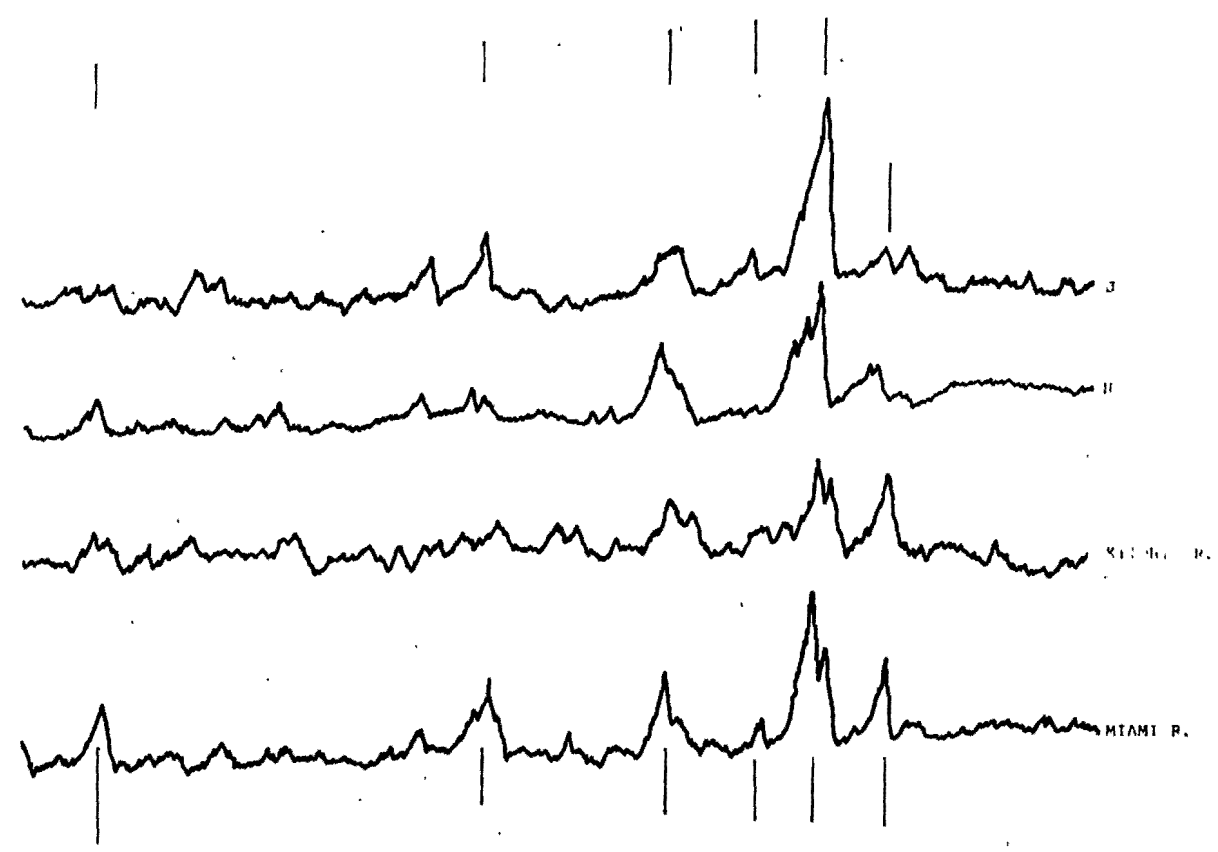

Figure 12b. X-ray diffraction "fingerprints" of heavy mineral samples from the southern part of Tillamook Bay with two river traces for comparison. 
less "noise" and patterns are much more distinct. Future work should be done with scan rates no faster than $2^{\circ}$ $2 \theta$ per minute.

When these traces are compared, a progressive change from east to west can be seen. The most easterly bay sample shows a marked resemblance to the Miami River sample: The most westerly bay sample seems to be a composite pattern with the characteristics of both the beach and older dunes. Figure $12 \mathrm{a}$ shows the $\mathrm{X}$-ray diffraction patterns of heavy minerals of four of the rivers feeding into Tillamook Bay, the Miami, the Wilson, the Kilchis and the Trask.

Each river can be seen to have a somewhat distinctive pattern. Figure $12 \mathrm{~b}$ shows two patterns from the middle of the bay with the Kilchis and Miami Rivers for comparison. The bay traces seem to be combinations of the two rivers. When the western parts of the bay are examined, the traces become difficult to match. This is an indication of thorough mixing in the southern and western parts of the bay.

The traces from the Kilchis, Trask and Wilson Rivers seem somewhat similar while the trace from the Miami River is different. The Miami River flows through an area of the Cowlitz Formation and perhaps this is enough to give the distinctive mineralogy. Kulm and others (1968) report essentially no differences in the heavy mineral 
composition of any of these rivers, except that the Trask River has 6 percent Titanaugite. Kulm's investigation did not include opaques and it is possible that the difference is in these minerals.

One other aspect of this type of technique needs consideration for future studies. Variability or variance at each sample location needs to be assessed. Two or three samples from each location should be processed and compared. Further, the technique of comparison of curves by eye is unnecessarily crude. Curves should be compared by a factor analysis or Fourier Analysis technique. This would require access to a computer for rapid comparisons. Even with the limitation of the "noisy" traces due to high scan speeds, the method shows promise in rapidly evaluating source areas of sediments. It seems that the beach and dunes of Tillamook spit are not primarily composed of sediments derived from Tillamook Bay as their X-ray diffraction "fingerprints" are distinctly different. The heavy mineral X-ray diffraction "fingerprints" show that the sediment source for the majority of the bay is from the rivers feeding into the bay. That part of the bay near the mouth, however, seems to have sediments derived from the beach and older (Pleistocene ?) dunes on the spit. The hooked shape of the spit also indicates a net inflow of sediments at the mouth of the bay. 


\section{Clay Mineralogy}

Two electron photomicrographs, Figure 13a and Figure 13b, show some of the -2 micron suspended sediment in the bay water. Most of the material seems to be amorphous or organic. In Figure 13a some of the plate like material looks like montmorillonite or illite and one object on the right side seems to have a hollow center or in other words is tubular. If this is not organic, it would likely by halloysite.

A sample of -2 micron material from this location was mounted for $\mathrm{X}$-ray diffraction using the technique of Glenn (1968, personal communication). This X-ray diffraction pattern shows a broad peak centered at $12 \mathrm{~A}^{\circ}$. and a smaller peak near $7 \mathrm{~A}^{\circ}$. The $12 \mathrm{~A}^{\circ}$ spacing is probably sodium saturated montmorillonite and the $7 \mathrm{~A}^{\circ}$ spacing indicates halloysite. Kaolinite is ruled out by the lack of a $3.6 \mathrm{~A}^{\circ}$ peak. 


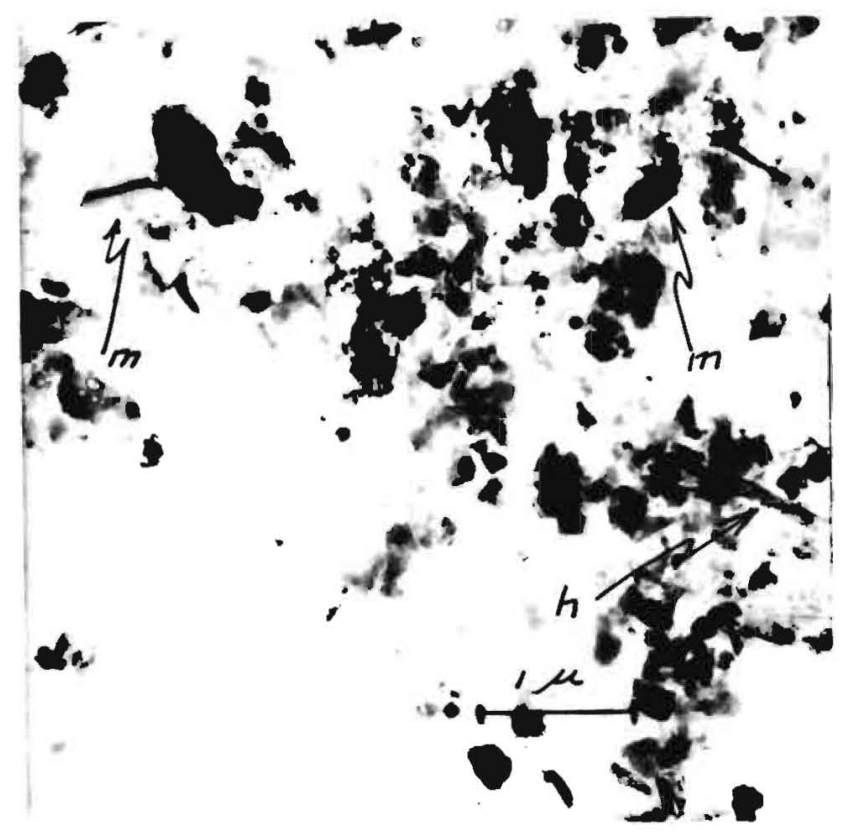

Figure 13a. Electron photomicrograph of a sample of the less than 2 micron suspended sediment in Tillamook Bay.

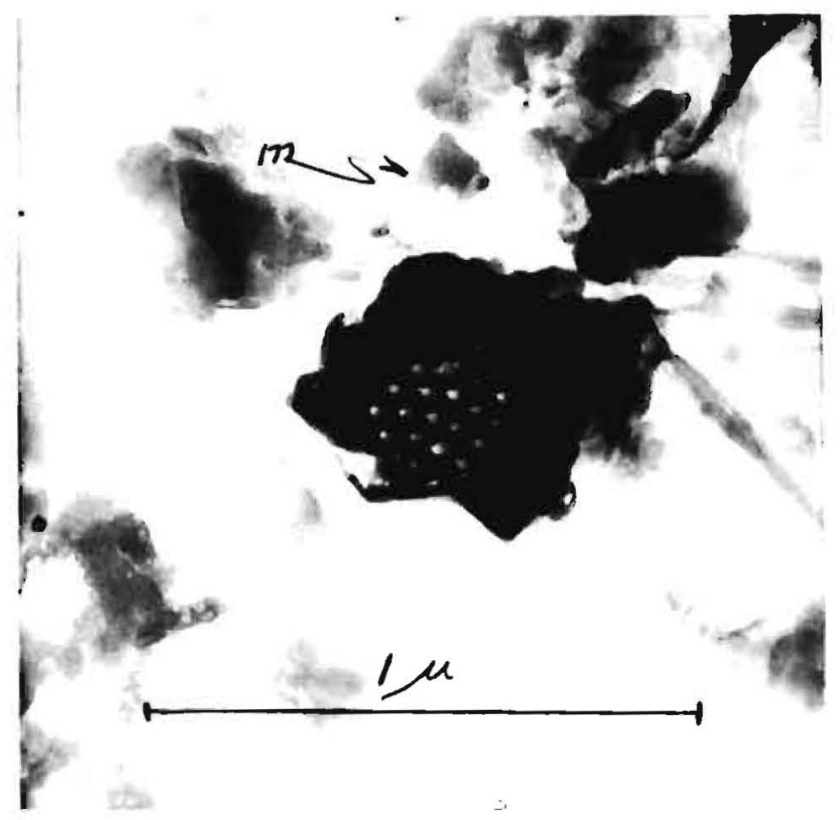

Figure 13b. Electron photomicrograph of a sample of the less than 2 micron suspended sediment in Tillamook Bay. 
SUMMARY

\section{CONCLUSIONS}

It can be seen that any sampling plan needs an input of sample variance. If no estimate of sample variance is known, a small pilot study will give a value which can be used to design the sample plan. If variance is not taken into account, for any study that utilizes sampling, it is likely that a greater degree of precision than is justified will be attributed to the results. Geological data is frequently displayed by use of contour or isopleth maps as this type of display increases the ease of geologic interpretation. The choice of contour intervals depends on the degree of precision of a station value and the density of stations. The first factor is not so well recognized as the second if published work is used as an indicator.

Granulometric data of sediments, when plotted on probability graph paper, frequently show attributes of being composed of more than one sedimentary population. Analysis of these individual populations would shed more light on the sedimentary process.

The technique of $x$-ray "fingerprinting" of heavy minerals is a rapid method of identifying sediment source 
areas and, while it should not replace the petrographic microscope, it could be used to guide the direction of petrographic examination.

Electron microscopy for clay mineralogy is probably not justified except for special applications. $x$-ray diffraction is much quicker and gives good results usually. The sedimentary facies in Tillamook Bay can be divided into three major categories using skewness and sorting as parameters. A small portion of the bay near the mouth has zero skewness and is very well sorted. Near the head of the bay an area of zero skewness and moderate sorting is found with most of the remainder of the bay containing sediments that are finely skewed and sorted from poor to well sorted.

When looking at sediment type (Folk 1954) the zero skewness, very well sorted area is mostly sand. The remainder of the bay is dominantly sandy silt. The area to the east of the old break in the spit is silty sand. Median grain size is coarse (less than 2 phi) near the mouth of the bay. The finer median grain sizes are found to the south, away from the mouth.

The history of Tillamook Bay from the earliest recorded time is one of filling. The filling at the present time is primarily from streams flowing into the bay with only a minor contribution from the ocean near the mouth of the bay. The rate of fill and whether filling is 
accelerating or not is not known. The future of Tillamook. Bay is one of continual filling unless steps are taken to reduce the input of sediment to the bay or a method found to remove sediment from the bay.

\section{FUTURE STUDIES}

Variance estimates for Tillamook Bay may or may not be typical of other bays, but a small pilot study such as the one done for this project could provide a rough estimate of variance to compare with this and other studies to see if extrapolation is possible. As previously noted, variance estimates for Tillamook Bay coincide fairly closely with those found by kelley and MoManus (1969) for continental shelf sediments.

In this study median phi seemed the most diagnostic measure for differentiating between stations, while sorting and skewness seemed the poorest. For a rapid determination of sediment type, one might choose percentage of sand and percentage of silt. Even though they are not quite as diagnostic, one could probably complete three or four samples for percentage of sand and percentage of silt, thereby increasing precision, in the same time required for one complete granulometric analysis. 
Bagnold, R. A., 1941, The physics of blown sand and desert dunes : Iondon, Methuen.

Baldwin, E. M., 1964, Ceology of Oregon: Eugene, Oregon, Univerelty of Oregon Cooperative Bookstore.

Bianton, J. 0., 1969, Energy dissipation in a tidal estuary: Jour. Ceophysical Research, v. 74; no. 23. p. 5460-5467.

Brown, H. B., Clark, G. D., and Pope, R, J., 1958, Closure of the breach in Bayocean Peninsula, Oregon: Procedings of the Amer. Soc. of Civil Engineers. Jour. of the waterways and Harbors Div.. Papax no. $1516, p, 1-20$.

Brown, R. D., Jx., Snavely, R. D., and Gower, H, D., 1956, Iyre formation (redefinition), northern olympia Poninaula; Washington: Am. Assoc. Petroleum Geologides Bul1.. v. 40, no. 1, p. 94-107.

Bu11, H. B.. 1962, Relation of textural. (CM) patterns to dopositelona 1 envixoniments of alluvial-ian deposites Jour. Bed. Patrology, v. 32, p. 211-216.

Burt, W. V., and McAllister, W. B., 1959, Recent studies in the hydrography of Oregon estuaries: Research Briefs, Oregon Figh Commission, v. 7., no. 1.

Cochran, W. G.. 1963, sampling techntques, 2nd ed.. New York, John Wiley and Sons, Inc.

Cooper, W. S., 1958, Coastal dunes of Oregon and Washington: Geol. Soc. America Mem. 72.

Dicken, S. N., 1954, Western Oregon and Washingtons in Freeman, $0 . H_{.}$, and Martin, H. H.. eds.., The Paciflc Northwest, 2nd ed., New York, John Viley and Sons, Inc.. p. 54-64.

Dodds, R. K., 1963, Geology of the Western half of the Svensen quadrangle, Oregon: University of Oregon maters thesis. (unpub.) 
Folk, R. I., 1968, Petrology of sedimentary rocks: 2nd ed., Austin, Texas, Hemphilis Book Store.

Fraser, H. J., 1935, Experimental study of the porosity and permeability of clastic sediments: Jour. of Geology, v. 43, p. 910-1010.

Friedman, G. M., 1961, Distinction between dune, beach, and river sands from their textural characteristics: Jour. Sed. Petrology, v. 31, p. 514-529..

1967. Dynamic processes and statistical parameters compared for size frequency distribution of beach and river sand: Jour. Sed. Petrology, v. 37, no. 2 , p. 327-354.

Howe, H. V., 1926, Astoria: Mid-Tertic type of Pacific Coast: Pan-American Geologist, v. 45, p. 295-306.

Kelly, J. C., and McManus, D. A., 1969, Optimizing sediment sampling plans: Marine Geology, v. 7, p. 465-471.

Kulm, I. D., and Byrne, J. V., 1966, Sedimentary response to hydrography in an Oregon estuary: Marine Geology, v. 4, p. 85-118.

Kulm, I. D., Scheidegger, K. F., Byrme, J. V., and Spigai, J. J.. 1968, A preliminary investigation of the heavy mineral suites of the coastal rivers and beaches of Oregon and northern California: The ore Bin, v. 30, no. 9, p. 165-180.

Krumbein, W. C., 1934, The probable error of sampling sediments for mechanical analysis: Am. Jour, of Science, v. 27, p. 204-214.

Krumbein, W. C., and Graybill, F. A., 1965, An introduction to statistical models in geology: New York, MCGraw-Hill.

Miller, R, H., 1966, Specialized analog computer resolves overlapping peaks: Anal. Chemistry, v. 38, p. 121A123A.

North, W. B., and Byrne, J. V., 1965, Coastal landsildes of northern Oregon: The Ore Bin, v. 27, no. 11, p. 217-241. 
Oser, R. K., 1972, Sedimentary components of northwest Pacific pelagic sediments: Jour. Sed. Petrology, v. 42, no. 2, p. 461-467.

otto, G. H., 1938, The sedimentation unit and its use in field sampling: Jour, of Geology, v. $46, p \cdot 569-582$.

Palmer, I. A., 1967, Marine terraces of California, Oregon and Washington: University of California. Ios Angeles, doctoral dissertation, (unpub.).

Passega, Renato, 1957, Texture as a characteristic of clastic deposition: Am. Assoc. Petroleum Geologists Bul1., v. 41, p. 1952-1984.

-n- 1964. Grain size representation by CM patterns as a geological tool: Jour. Sed. Petrology, v. 34 . p. $830-847$.

Pettijohn, F. J.. 1957, Sedimentary rocks; 2nd ed., New York, Harper and Row.

Plumley, W. J., 1948, Black Hills terrace gravels: a study in sediment transport: Jour. of Geology. v. 55, P. 526-577.

Pritchard, M. C., 1955, Estuarine circulation patterns: Proceedings of the Am. Soc. of Civil Engineers. v. 81, p. 1-11.

Pryor, W. A., and Hester, N. C., 1969, X-ray diffraction analysis of heavy minerals: Jour. Sed. Petrology, v. 39, no. 4, p. 1384-1389.

Rittenhouse, Gordon, 1943, Sedimentation near junction of Maquoketa and Mississippi Rivers - a discussion: Jour. Sed. Petrology, v. 13, p. 40-42.

Royse, C. F., 1968, Recognition of fluvial environments by particle-size characteristics: Jour. Sed. Petrology, v. 38, no. 4, p. 1171-1178.

Schlicker, H. G., Deacon, R. J., Beaulleu, J, D., and olcott, G. W.. 1972. Environmental geology of the coastal region of Tillamook and Clatsop Countles, oregon: Oregon Dept. Geology and Mineral Industries. Buli. 74.

Sheffè, H., 1959. The analysis of variance: New York, John Wiley and Sons. 


\section{APPENDIX}

GRANULOMETRIC DATA FOR SAMPIES FROM TILILAMOOK BAY. LOCATION MAP WITH STATION IDENTIFICATION ON LAST PAGE OF APPENDIX. STATIONS TABULATED FROM NORTH TO SOUTH.

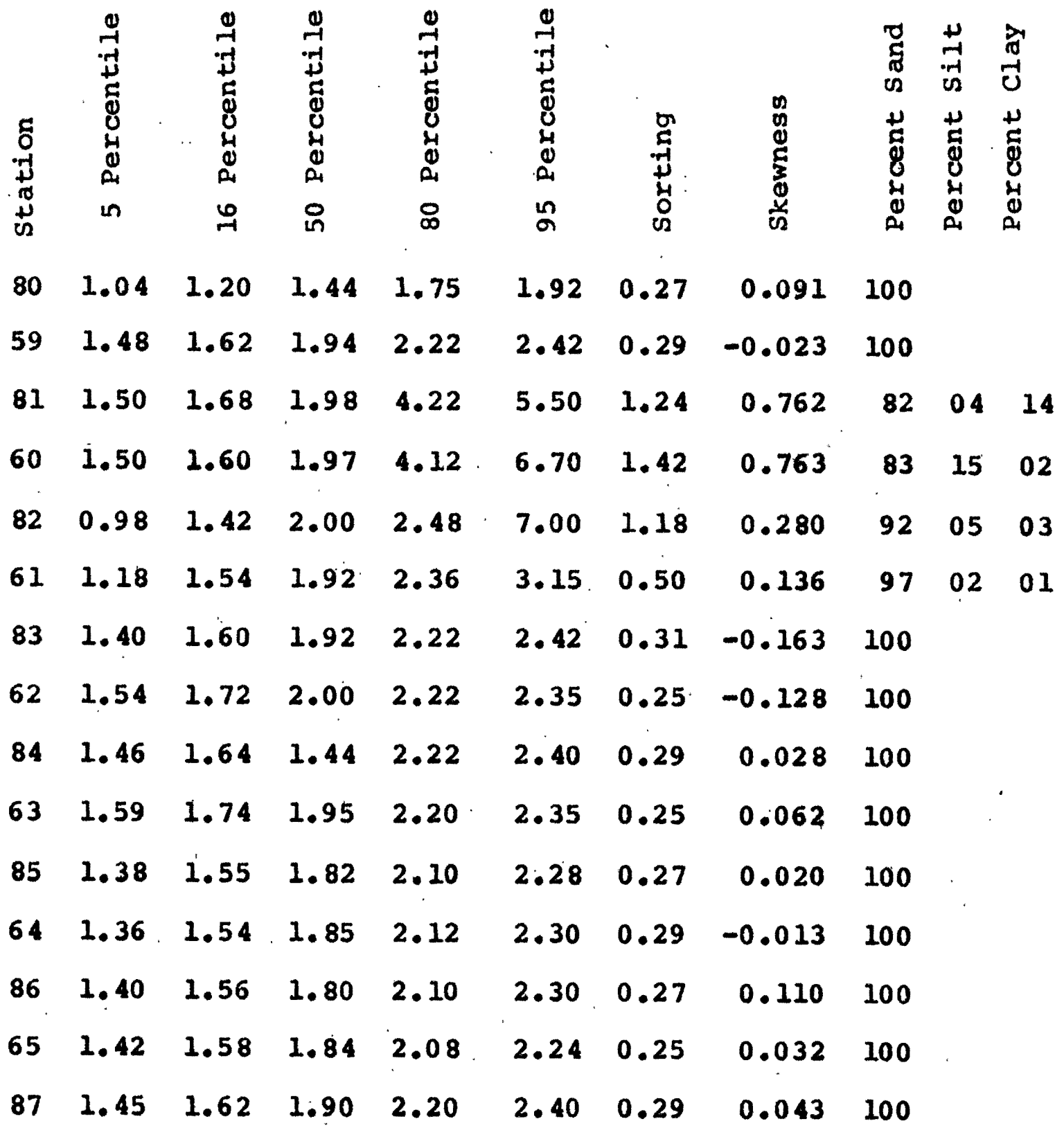




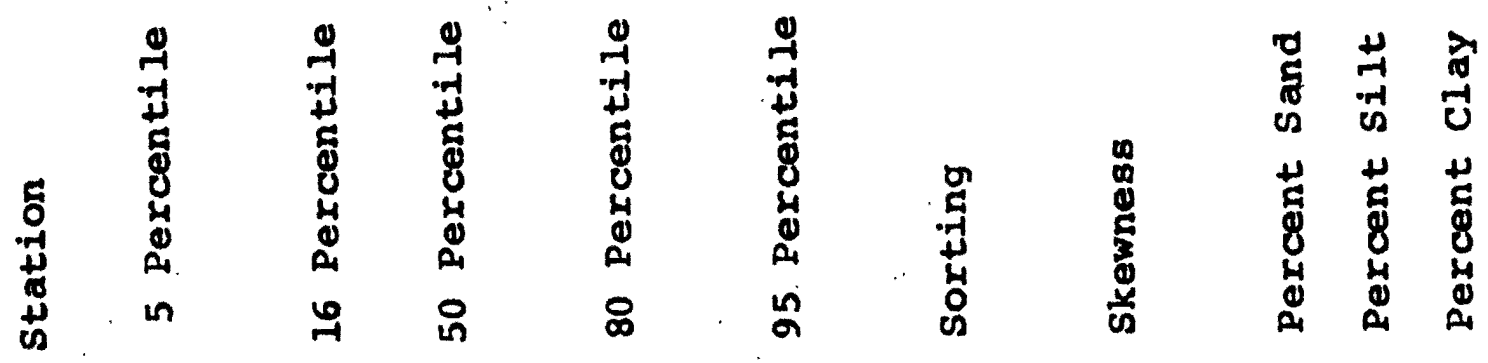

$\begin{array}{lllllllll}66 & 1.55 & 1.72 & 1.99 & 2.25 & 2.40 & 0.26 & -0.027 & 100\end{array}$

$\begin{array}{lllllllll}88 & 1.40 & 1.54 & 1.86 & 2.10 & 2.30 & 0.28 & 0.028 & 100\end{array}$

$\begin{array}{lllllllll}67 & 1.50 & 1.65 & 1.92 & 2.20 & 2.35 & 0.26 & 0.024 & 100\end{array}$

$\begin{array}{llllllllll}90 & 1.20 & 1.68 & 2.00 & 2.44 & 3.22 & 0.40 & 0.271 & 97 & 03\end{array}$

$\begin{array}{lllllllllll}69 & 1.05 & 1.60 & 2.30 & 4.06 & 7.04 & 1.67 & 0.465 & 84 & 12 & 04\end{array}$

$\begin{array}{lllllllllll}89 & 1.20 & 1.70 & 2.12 & 2.68 & 7.10 & 1.14 & 0.415 & 91 & 08 & 01\end{array}$

$\begin{array}{llllllllll}68 & 1.08 & 1.74 & 2.05 & 2.34 & 4.30 & 0.64 & 0.182 & 94 & 06\end{array}$

$\begin{array}{lllllllllll}37 & 1.55 & 1.72 & 2.08 & 2.78 & 10.00 & 1.55 & 0.597 & 87 & 06 & 07\end{array}$

$\begin{array}{llllllllll}36 & 1.60 & 1.78 & 2.06 & 2.84 & 2.65 & 0.42 & 0.298 & 98 & 02\end{array}$

$\begin{array}{lllllllllll}77 & 1.64 & 1.92 & 2.30 & 2.70 & 4.40 & 0.61 & 0.274 & 94 & 03 & 03\end{array}$

$\begin{array}{llllllllll}38 & 1.92 & 1.96 & 2.09 & 2.48 & 2.85 & 0.28 & 0.549 & 97 & 03\end{array}$

$\begin{array}{llllllllll}78 & 1.38 & 1.55 & 1.84 & 2.22 & 2.52 & 0.34 & 0.163 & 98 & 02\end{array}$

$\begin{array}{llllllllll}39 & 1.65 & 1.82 & 2.36 & 5.44 & 6.50 & 1.64 & 0.705 & 54 & 46\end{array}$

\begin{tabular}{lllllll|llll}
41 & 2.10 & 2.42 & 2.75 & 5.82 & 7.88 & 1.73 & 0.790 & 74 & 21 & 05
\end{tabular}

$\begin{array}{lllllllllll}40 & 2.10 & 2.40 & 2.90 & 5.95 & 8.16 & 1.81 & 0.727^{\prime} & 66 & 18 & 06\end{array}$

$\begin{array}{lllllllllll}43 & 1.68 & 1.84 & 2.15 & 2.44 & 2.66 & 0.30 & -0.003 & 99 & 01\end{array}$

$\begin{array}{llllllllll}42 & 1.68 & 1.86 & 2.16 & 2.45 & 2.65 & 0.29 & -0.001 & 99 & 01\end{array}$

$\begin{array}{llllllllll}45 & 0.64 & 1.46 & 1.88 & 2.26 & 2.54 & 0.49 & -0.178 & 99 & 01\end{array}$

$\begin{array}{lllllllllll}44 & 0.62 & 1.54 & 1.94 & 2.28 & 2.52 & 0.50 & -0.231 & 99 & 01\end{array}$

$\begin{array}{lllllllllll}47 & 2.00 & 2.46 & 3.30 & 5.02 & 6.66 & 1.35 & 0.393 & 67 & 31 & 02\end{array}$ 


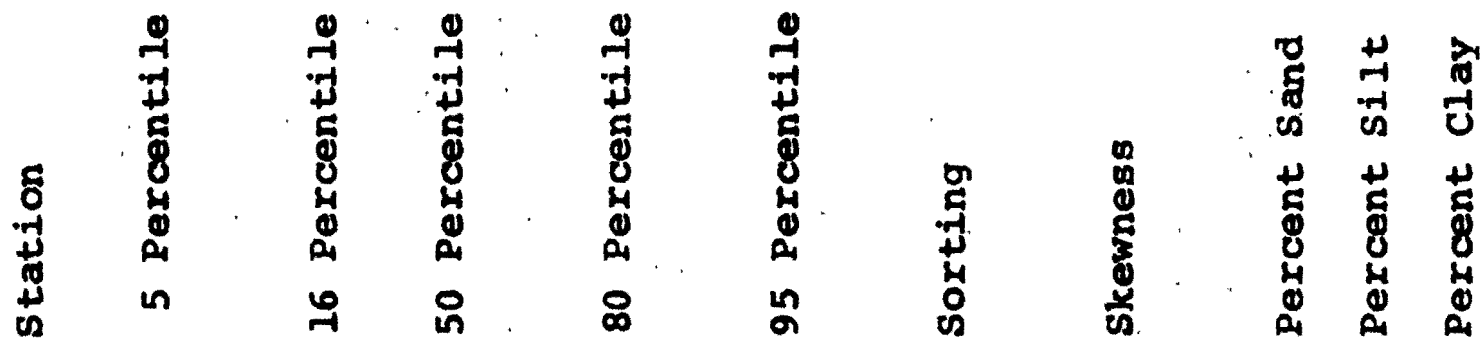

$\begin{array}{lllllllllll}46 & 2.10 & 2.50 & 3.28 & 5.40 & 7.18 & 1.49 & 0.499 & 71 & 27 & 02\end{array}$ $\begin{array}{llllllllll}49 & 1.25 & 1.75 & 2.25 & 2.50 & 2.72 & 0.41 & -0.347 & 99 & 01\end{array}$

$\begin{array}{lllllllll}48 & 1.64 & 2.04 & 2.30 & 2.56 & 2.75 & 0.30 & -0.114 & 100\end{array}$

$\begin{array}{lllllllllll}51 & 1.56 & 2.16 & 2.74 & 4.48 & 7.00 & 1.40 & 0.318 & 78 & 10 & 02\end{array}$ $\begin{array}{lllllllllll}50 & 1.65 & 2.18 & 2.74 & 4.70 & 8.20 & 1.62 & 0.612 & 76 & 09 & 05\end{array}$ $\begin{array}{lllllllllll}53 & 1.70 & 2.42 & 3.34 & 5.95 & 9.60 & 2.08 & 0.531 & 61 & 31 & 08\end{array}$ $\begin{array}{lllllllllll}52 & 1.34 & 2.00 & 2.75 & 4.98 & 6.36 & 1.51 & 0.567 & 76 & 23 & 01\end{array}$ $\begin{array}{lllllllllll}28 & 1.96 & 2.12 & 2.32 & 4.95 & 7.55 & 1.55 & 0.865 & 82 & 15 & 03\end{array}$ $\begin{array}{llllllllll}29 & 1.50 & 1.66 & 1.96 & 2.24 & 2.54 & 0.30 & 0.041 & 98 & 02\end{array}$ $\begin{array}{lllllllllll}31 & 1.70 & 1.92 & 2.56 & 5.54 & 8.40 & 0.92 & 0.695 & 70 & 24 & 06\end{array}$ $\begin{array}{llllllllll}30 & 2.04 & 2.26 & 2.62 & 2.86 & 3.50 & 0.37 & 0.144 & 96 & 04\end{array}$ $\begin{array}{lllllllllll}10 & 1.64 & 1.88 & 2.25 & 4.06 & 7.95 & 1.50 & 0.504 & 84 & 11\end{array}$

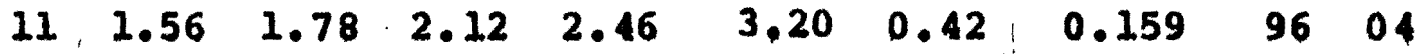
$\begin{array}{lllllllllll}12 & 1.58 & 1.80 & 2.12 & 2.50 & 4.34 & 0.59 & 0.347 & 95 & 04 & 01\end{array}$ $\begin{array}{lllllllllll}13 & 1.60 & 1.86 & 2.22 & 2.62 & 4.20 & 0.58 & 0.274 & 95 & 04 & 01\end{array}$

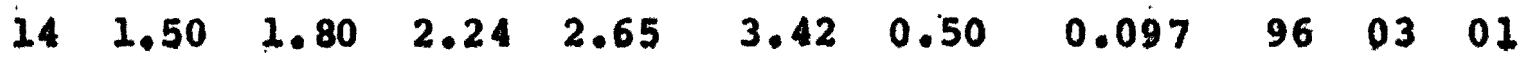
$\begin{array}{lllllllllll}15 & 1.60 & 1.84 & 2.16 & 2.56 & 4.10 & 0.56 & 0.391 & 95 & 03 & 02\end{array}$ $\begin{array}{lllllllllll}16 & 1.64 & 1.90 & 2.30 & 3.02 & 6.50 & 1.03 & 0.500 & 90 & 07 & 03\end{array}$ $\begin{array}{lllllllllll}17 & 1.64 & 1.84 & 2.18 & 2.64 & 4.86 & 0.69 & 0.407 & 93 & 06 & 01\end{array}$ $\begin{array}{lllllllllll}18 & 1.54 & 1.80 & 2.22 & 2.66 & 4.55 & 0.67 & 0.290 & 94 & 05 & 01\end{array}$ 


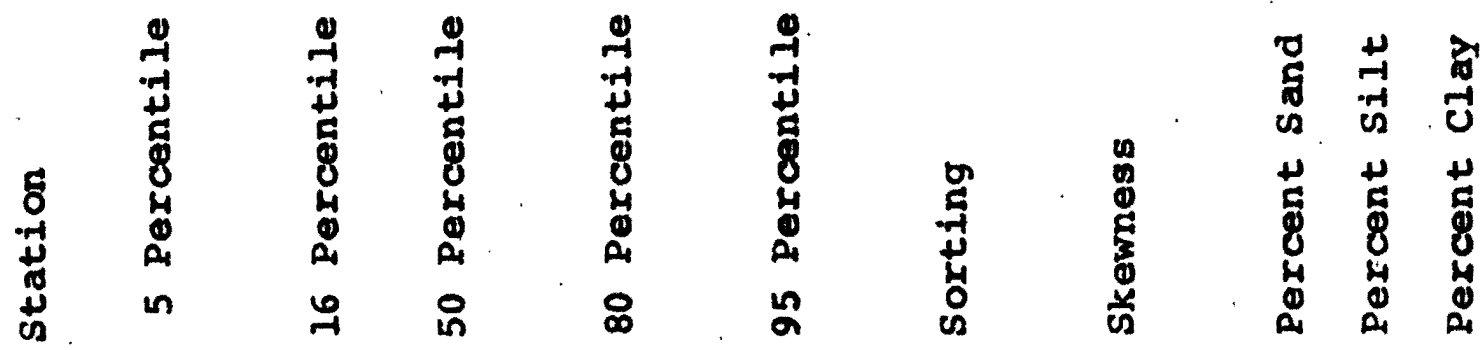

$\begin{array}{lllllllllll}33 & 2.04 & 3.84 & 5.25 & 7.00 & 8.40 & 1.75 & 0.049 & 19 & 74 & 07\end{array}$ $\begin{array}{lllllllllll}32 & 1.28 & 1.58 & 2.04 & 2.50 & 4.84 & 0.77 & 0.292 & 93 & 05 & 02\end{array}$

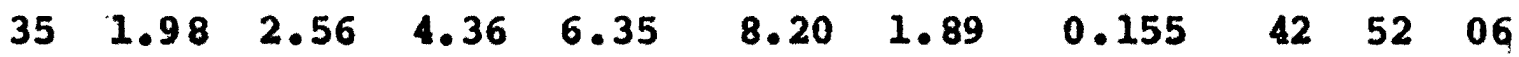
$\begin{array}{lllllllllll}34 & 1.90 & 2.42 & 3.66 & 5.30 & 7.25 & 1.53 & 0.240 & 58 & 44 & 04\end{array}$ $\begin{array}{lllllllllll}79 & 1.64 & 2.12 & 2.45 & 3.90 & 6.65 & 1.20 & 0.653 & 84 & 13 & 03\end{array}$ $\begin{array}{lllllllllll}58 & 1.78 & 2.00 & 2.44 & 4.15 & 6.30 & 1.22 & 0.649 & 83 & 16 & 01\end{array}$ $\begin{array}{lllllllll}57 & 0.44 & 1.12 & 1.78 & 2.36 & 2.74 & 0.66 & -0.115 & 100\end{array}$ $\begin{array}{lllllllll}56 & 0.38 & 1.02 & 1.72 & 2.28 & 2.60 & 0.65 & -0.159 & 100\end{array}$

$\begin{array}{lllllllllll}1 & 0.30 & 1.00 & 1.80 & 2.72 & 7.60 & 1.54 & 0.260 & 91 & 05 & 04\end{array}$ $\begin{array}{lllllllllll}2 & 0.62 & 1.36 & 2.12 & 5.03 & 9.00 & 2.19 & 0.614 & 80 & 14 & 06\end{array}$ $\begin{array}{lllllllllll}3 & 0.44 & 1.50 & 2.05 & 6.24 & 11.00 & 2.79 & 0.731 & 78 & 10 & 12\end{array}$ $\begin{array}{lllllllllll}4 & 0.30 & 1.00 & 1.86 & 2.92 & 5.80 & 1.31 & 0.359 & 90 & 06 & 04\end{array}$ $\begin{array}{lllllllllll}5 & 0.62 & 1.25 & 2.40 & 6.08 & 9.50 & 2.55 & 0.561 & 73 & 19 & 06\end{array}$ $\begin{array}{lllllllllll}6 & 0.46 & 1.20 & 2.14 & 5.30 & 9.50 & 2.39 & 0.585 & 79 & 12 & 09\end{array}$

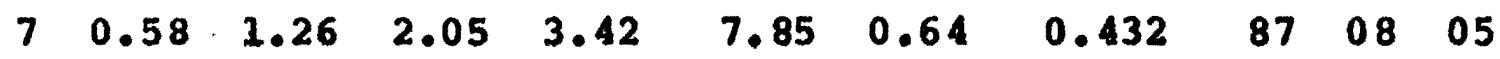
$\begin{array}{lllllllllll}8 & 0.90 & 1.50 & 2.25 & 4.44 & 8.08 & 1.82 & 0.557 & 82 & 13 & 05\end{array}$ $\begin{array}{lllllllllll}9 & 0.50 & 1.26 & 2.15 & 4.15 & 9.50 & 2.09 & 0.509 & 83 & 10 & 07\end{array}$ $\begin{array}{lllllllllll}91 & 2.96 & 3.96 & 4.75 & 7.16 & 8.80 & 1.69 & 0.446 & 15 & 76 & 09\end{array}$ $\begin{array}{llllllllll}70 & 3.25 & 4.50 & 5.38 & 6.26 & 6.80 & 0.98 & -0.100 & 09 & 91\end{array}$ $\begin{array}{lllllllllll}92 & 3.75 & 3.95 & 4.26 & 6.50 & 8.45 & 1.35 & 0.769 & 20 & 73 & 07\end{array}$ 


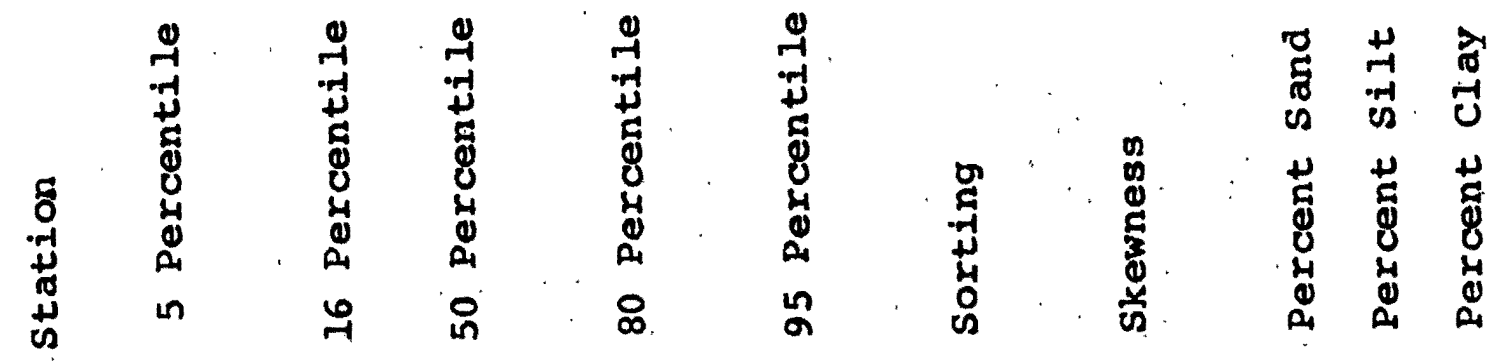

$\begin{array}{llllllllll}71 & 3.86 & 4.12 & 5.00 & 6.26 & 6.88 & 0.99 & 0.211 & 06 & 94\end{array}$ $\begin{array}{lllllllllll}19 & 2.65 & 3.44 & 4.64 & 7.50 & 12.50 & 2.51 & 0.402 & 34 & 52 & 14\end{array}$ $\begin{array}{lllllllllll}20 & 2.68 & 3.45 & 4.72 & 7.50 & 12.00 & 2.43 & 0.467 & 31 & 55 & 14\end{array}$ $\begin{array}{lllllllllll}21 & 2.55 & 3.45 & 4.74 & 7.84 & 12.00 & 2.53 & 0.469 & 30 & 55 & 15\end{array}$ $\begin{array}{lllllllllll}22 & 2.18 & 2.94 & 4.09 & 6.65 & 9.90 & 2.10 & 0.443 & 48 & 42 & 10\end{array}$ $\begin{array}{lllllllllll}23 & 2.20 & 3.20 & 4.46 & 7.30 & 12.00 & 2.50 & 0.462 & 36 & 51 & 13\end{array}$ $\begin{array}{lllllllllll}24 & 2.34 & 3.24 & 4.64 & 7.40 & 14.00 & 2.81 & 0.466 & 36 & 51 & 13\end{array}$ $\begin{array}{lllllllllll}25 & 2.15 & 3.14 & 4.45 & 7.00 & 12.30 & 2.50 & 0.433 & 38 & 49 & 13\end{array}$ $\begin{array}{lllllllllll}26 & 2.25 & 3.14 & 4.30 & 7.62 & 11.20 & 2.48 & 0.512 & 42 & 44 & 14\end{array}$ $\begin{array}{lllllllllll}27 & 2.08 & 2.98 & 4.12 & 7.00 & 10.50 & 2.81 & 0.474 & 46 & 41 & 13\end{array}$ $\begin{array}{llllllllll}93 & -0.28 & 0.40 & 1.16 & 1.90 & 2.38 & 0.78 & -0.048 & 98 & 02\end{array}$ $\begin{array}{llllllllll}72 & -0.14 & 0.44 & 1.38 & 2.05 & 2.55 & 0.81 & -0.149 & 98 & 02\end{array}$ $\begin{array}{llllllllll}95 & -2.50 & -1.30 & 0.60 & 1.74 & 2.50 & 1.52 & -0.245 & 97 & 03\end{array}$ $\begin{array}{llllllllll}74 & -1.11 & -0.28 & 0.92 & 1.62 & 2.04 & 0.95 & -0.276 & 98 & 02\end{array}$ $\begin{array}{llllllllll}97 & 0.29 & 1.02 & 1.96 & 2.75 & 3.50 & 0.92 & -0.063 & 97 & 03\end{array}$ $\begin{array}{lllllllllll}76 & 0.24 & 1.06 & 2.14 & 3.25 & 4.82 & 1.13 & 0.093 & 91 & 08 & 01\end{array}$ $\begin{array}{lllllllllll}96 & 1.26 & 1.92 & 3.06 & 4.14 & 7.24 & 1.46 & 0.186 & 78 & 18 & 04\end{array}$ $\begin{array}{lllllllllll}75 & 1.46 & 2.14 & 3.40 & 4.76 & 6.00 & 1.34 & 0.092 & 68 & 31 & 01\end{array}$ 


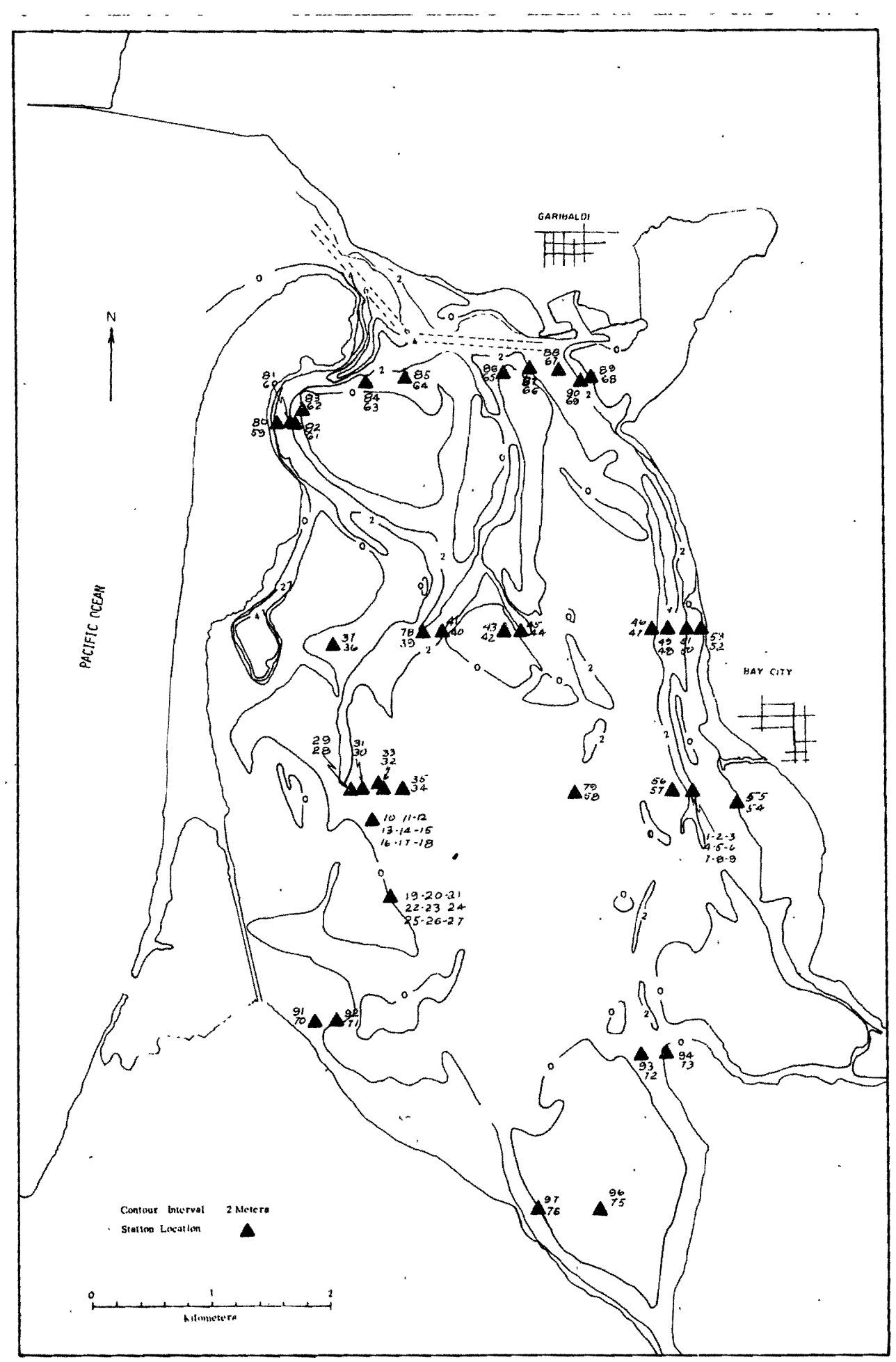

67 


\title{
GRANULONETRIC ANALYSIS OF RECENT SEDIMENTS \\ OF TILIAMOOK BAY, OREGON
}

\section{by}

gENARRO WIILIAM AVOLIO

A thesis submitted in partial fulfillment of the requidrements for the degree of

\author{
MASTER OF SCIENCE \\ in \\ EARPH SCIENCE
}

\section{Portland State University 1973}


Snavely, P. D., and Baldwin, E. M., 1948, Silatz River Volcanic series, northwestern Oregon: Am. Assoc. Petroleum Geologists Bull., v. 32 , no. 5, p. 805812 .

Snavely, R. D., Macleod, N. S., and Rau, W. W., 1969, Geology of the Newport area, Oregon: The Ore Bin, v. 31. nos. 2 and 3.

Snavely, P. D., Macleod, N. S., and Wagner, H. C., 1968, Tholeiftic and alkalic basalts of the Bocene siletz River volcanics, Oregon Coast Range: Am. Jour. of science, v. 266, no. 6 , p. 454-48I.

Snavely, P. D. , and Vokes, H, E., 1949, Geology of the coastal area between Cape Kiwanda and Cape Foulweather, Oregon: U. S. Geol. Survey Oil and Gas Investigation Map OM 97.

Sonu, C. J., 1972, Bimodal composition and cyclic characteristics of beach sediment in continuously changing profiles: Jour. Sed. Petrology, v. 42, no. 4. p. 852-857.

Swensen, F. A., 1942 , Sedimentation near junction of Maquoketa and Mississippi Rivers: Jour. Sed. Petrology, v. 12 , p. 3-9.

Twenhofel, W. H., 1943, Origin of the black sands of the coast of southwest Oregon. Oregon Dept. Geology and Mineral Industries, Bull. 24.

- - 1946, Mineralogical and physical composition of the sands of the Oregon coast from Coos Bay to the mouth of the Columbia River: Oregon Dept. Geology and Mineral Industries, Bull, 30.

Udden, J. A., 1914. Mechanical composition of clastic sediments: Geol. Soc. America Bull., v. 25, p. 655-744.

Visher, G. S., 1969, Grain size distributions and depositional processes: Jour. Sed. Petrology, v. 39 . no. 3, p. $1074-1106$.

Warren, W. C., Norbisrath, H, , and Grivetti, R. M., 1945, Geology of northwest Oregon wegt of the Willamette River and north of latitude $45^{\circ} 15^{\prime}: \mathrm{U}$. S. Geol. Survey $0 i l$ and Gas Investigation Preliminary Map 42. 